The University of Maine

\title{
DigitalCommons@UMaine
}

Earth Science Faculty Scholarship

Earth Sciences

1983

\section{Morphology and Dynamics of the Rock Glaciers in Southern Victoria Land, Antarctica}

Jon M. Hassinger

Paul Andrew Mayewski

University of Maine, paul.mayewski@maine.edu

Follow this and additional works at: https://digitalcommons.library.umaine.edu/ers_facpub

Part of the Geomorphology Commons, and the Glaciology Commons

\section{Repository Citation}

Hassinger, Jon M. and Mayewski, Paul Andrew, "Morphology and Dynamics of the Rock Glaciers in Southern Victoria Land, Antarctica" (1983). Earth Science Faculty Scholarship. 183.

https://digitalcommons.library.umaine.edu/ers_facpub/183 
Arctic and Alpine Research, Vol. 15, No. 3, 1983, pp. 351-368

\title{
MORPHOLOGY AND DYNAMICS OF THE ROCK GLACIERS IN SOUTHERN VICTORIA LAND, ANTARCTICA
}

\author{
Jon M. Hassinger* and Paul A. Mayewski \\ Department of Earth Sciences, University of New Hampshire \\ Durham, New Hampshire 03824, U.S.A.
}

\begin{abstract}
A baseline study of rock glaciers located in the ice-free valleys of southern Victoria Land, Antarctica, was performed in order to determine their usefulness as proxy tools in studies of climatic change. The distribution of the 32 rock glaciers identified in this analysis is principally attributed to site-specific controls including proximity to localized moisture sources and low ambient site temperature controlled by elevation, orientation, and topographic shading.

The relative activity of rock glaciers and their vertical velocity profiles are inferred from termini morphology. Thirty-eight percent of the rock glaciers are stagnant, $41 \%$ show velocity decreasing rapidly with depth, and velocity decreases gradually with depth in the remaining $21 \%$.

A structural-compositional model for 11 rock glaciers, constructed from geophysical data, consists of an ice-free layer from 0.3 to $3 \mathrm{~m}$ thick that is underlain by either interstitially frozen debris or ice. Horizontal velocities of 1 to $3 \mathrm{~cm} \mathrm{yr}^{-1}$, surface lowerings ranging up to $1 \mathrm{~cm} \mathrm{yr}$, and infinitesimal strain rates of $10^{-4} \mathrm{yr}^{-1}$ were measured for the lower geophysically defined layer of one rock glacier.

Analyses of rock glacier dynamics and internal structure are considered useful in studies of climatic change since (1) the response of the ice-free surface layer and the "core" have the potential for being directly related to site specific thermal regimes and/or the availability of moisture and (2) the responsiveness of these structural units varies from immediate for the surface layer to greater than that of true glaciers for the rock glacier "core."
\end{abstract}

\section{INTRODUCTION}

Rock glaciers are landforms common to alpine and polar regions throughout the world and have, because of their permafrost composition, proven useful as indicators of climatic change. Analyses of the distribution of rock glaciers have added a new dimension to Holocene paleoclimate studies (e.g., Wahrhaftig and Cox, 1959; Ellis and Calkin, 1979; Morris, 1981) particularly in areas

*Present address: Exxon Co. U.S.A., Alaska/Pacific Division, P.O. Box 4279, Houston, Texas 77001, U.S.A. where traditional forms of glaciogeological evidence are lacking (Dawson, 1977; Luckman and Crockett, 1978). Continued refinement in the use of rock glaciers in such studies requires an understanding of the relative importance of climatic and nonclimatic controls on rock glacier development as well as the quantification of rock glacier responses to changes in these controls.

Rock glaciers, which may have several different geneses (Corte, 1976; Barsch, 1978; Barsch et al., 1979; Vick, 1981) are usually identified on the basis of morphological evidence such as the presence of lobes, consisting mainly 
of coarse debris, that show some evidence of flow (Barsch, 1977; Luckman and Crockett, 1978). Downslope movement of rock glaciers ranges from 5 to $100 \mathrm{~cm} \mathrm{yr}^{-1}$ (White, 1971; Osborn, 1975; Barsch, 1977; Haeberli et al., 1979). The term "rock glacier" has been applied to a wide variety of geomorphic forms, ranging from felsenmeer to debris-covered glaciers, that exhibit varying degrees of morphological similarity. Wahrhaftig and Cox (1959), Ommanney (1976), and White $(1971,1976,1981)$ provide excellent summaries of morphological descriptions of various glaciogeomorphic features referred to in the literature as rock glaciers.

The purpose of this study is to interpret observed changes in the dynamics of rock glaciers found in the ice- free valleys of southern Victoria Land, Antarctica, in the context of climatic change. An analysis of the distribution of rock glaciers is used to determine the relative importance of various climatic, geologic, and geomorphic controls on rock glacier development. The internal structure of these rock glaciers is inferred from shallow seismic refraction and electrical resistivity profiles. Finally, rockglacier flow regimes are quantified by an analysis of $10 \mathrm{yr}$ of three-dimensional movement data, surficial micromovement experiments, and morphological evidence. A synthesis of these data is used to illustrate the manner in which results from monitoring rock glacier dynamics can be utilized in studies of climatic change in the icefree valley region.

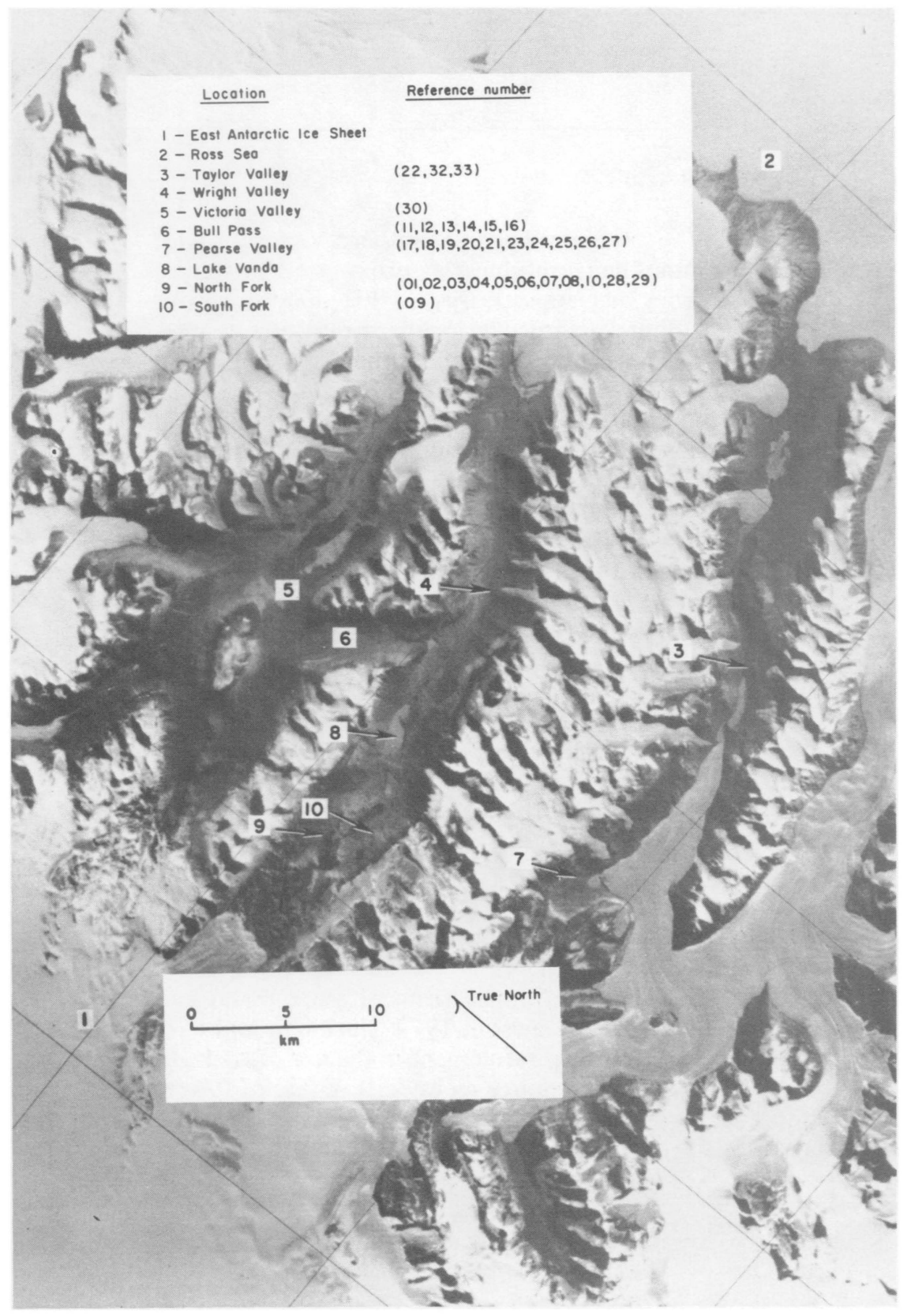

FIGURE 1. Geographic concentrations of rock glaciers in the ice-free valleys of southern Victoria Land, Antarctica (ERTS image of U.S. Geological Survey). Reference numbers are keyed to location maps (Figures 3-6). 


\section{STUDY AREA}

The ice-free region of southern Victoria Land, Antarctica (Figure 1), is bordered on three sides by the East Antarctic ice sheet and its outlet glaciers and on the fourth side by the Ross Sea. Included with this ice-free region are three major east-west trending valley systems - Taylor, Wright, and Victoria, comprising approximately $240 \mathrm{~km}^{2}$, and lying at elevations of 400 to $1000 \mathrm{~m}$ above sea level (Calkin, 1971). These valleys were selected for study because (1) they contain the majority of rock glaciers in southern Victoria Land; (2) the rock glaciers found within these valleys occur at various elevations and orientations, and (3) because the region is relatively simple climatically and, therefore, one in which relationships between rock glacier development and various components of climate can easily be studied.

The valleys are considered polar deserts (Bull, 1966) with mean annual temperatures of $-20^{\circ} \mathrm{C}$, precipitation of only 3 to $10 \mathrm{~g} \cdot \mathrm{cm}^{-2} \cdot \mathrm{yr}^{-1}$, and a strong positive radiation balance (Bull, 1966; Thompson et al., 1971; Colacino and Stocchino, 1978). Precipitation is limited to snow or ice which usually sublimates within several days of falling (Bull, 1966). Extreme aridity is further indicated by the presence of undrained ponds with high salinities, efflorescence of salts in soils, the crystallization of the extremely deliquiescent mineral antarcticite $\left(\mathrm{CaCl}_{2}\right.$. $6 \mathrm{H}_{2} \mathrm{O}$ ), and relative humidities ranging as low as 10 to 20\% (Bull, 1966; Wilson, 1979).

\section{METHODS}

Thirty-two rock glaciers were identified on regional aerial photographs, covering approximately $85 \%$ of the ice-free valleys of southern Victoria Land, by the presence of lobes or tongues of debris that have a marked break in slope at their edges and that show evidence of current or former movement. The rock glaciers cluster (Figure 1) in western Wright, Pearse, and upper Taylor valleys and Bull Pass.

\section{Classification}

A morphological classification scheme modified after Barsch (1977) and Corte (1976) was used to group rock glaciers with common geomorphic settings. The five types of rock glacier settings identified in this study are those found at the base of talus slopes (type 1a), on talus slopes (type 1b), in cirques (type 2a), below cirques (type 2b), and directly adjacent to glaciers (type $2 \mathrm{c}$ ). This morphological classification scheme was used in preference to recently advocated genetic systems (Ellis and Calkin, 1979; White, 1981; Harris, 1981) that associate rock glacier shape with their mode of formation, because rock glaciers in the Antarctic with the same apparent origin exhibit a variety of shapes.

\section{Geomorphic, Geologic, and Climatic Controls}

The influences of geomorphic, geologic, and climatic controls on rock-glacier development were investigated at each site. Geomorphic variables, including the surface shape of the rock glacier and its source area were measured in the field and from aerial photographs by means of standard photogrammetric techniques (Lillesand and Keifer, 1979). Reports by McKelvey and Webb (1962) were used to examine the influence of geologic variables such as regional bedrock structure, lithology, and strike and dip of joints and faults.

Climatic variables were indirectly described by noting rock glacier orientation, head elevation, and the proximity of rock glacier sites to moisture sources such as runoff from glaciers and snowpatches. Maximum yearly totals of potential incident solar radiation at rock glaciers were estimated by means of a computer program (Swift, 1976).

\section{MORPHOLOGY}

Rock glacier morphology was described using a format slightly modified from Johnson (1973).

\section{INTERNAL STRUCTURE}

The internal structure of 11 out of 32 rock glaciers in the data set was inferred on the basis of shallow seismic refraction profiles and electrical resistivity soundings. Seismic refraction data were collected with a single channel signal enhancement engineering seismograph (Bison model 1507B) using a 4-kg sledgehammer as a signal source. Lines were extended 30 to $50 \mathrm{~m}$ depending on signal strength and system noise and were located on horizontal surfaces to minimize topographic corrections. Sixty-five percent of the lines were reversed permitting calculation of true velocities and dips of refracting layers (Telford et al., 1976). Multilayered models were fit to travel-time data on the basis of straight lines visually constructed to minimize the residuals between observed and modeled travel times. Dipping layer models were constrained by the conditions of reciprocity.

Electrical resistivity soundings were conducted using an earth resistivity meter (Model ER-2, Soil Test). Direct current from a 90-volt battery was applied to copperplated steel electrodes placed in the Wenner electrode configuration. Continuous data were collected to a depth of approximately $30 \mathrm{~m}$ by expanding the electrode spacing from 2 to $32 \mathrm{~m}$. Resistivity values were converted to apparent resistivities and plotted on log-log graph paper. Initial models, obtained by curve-matching techniques (Orellana and Mooney, 1966; Dobrin, 1976) were used as input for a numerical inversion computer program (Davis, 1979) that utilizes a digital linear filter approach.

Control on the interpretation of seismic $P$-wave velocities and resistivities was provided not only by a limited 

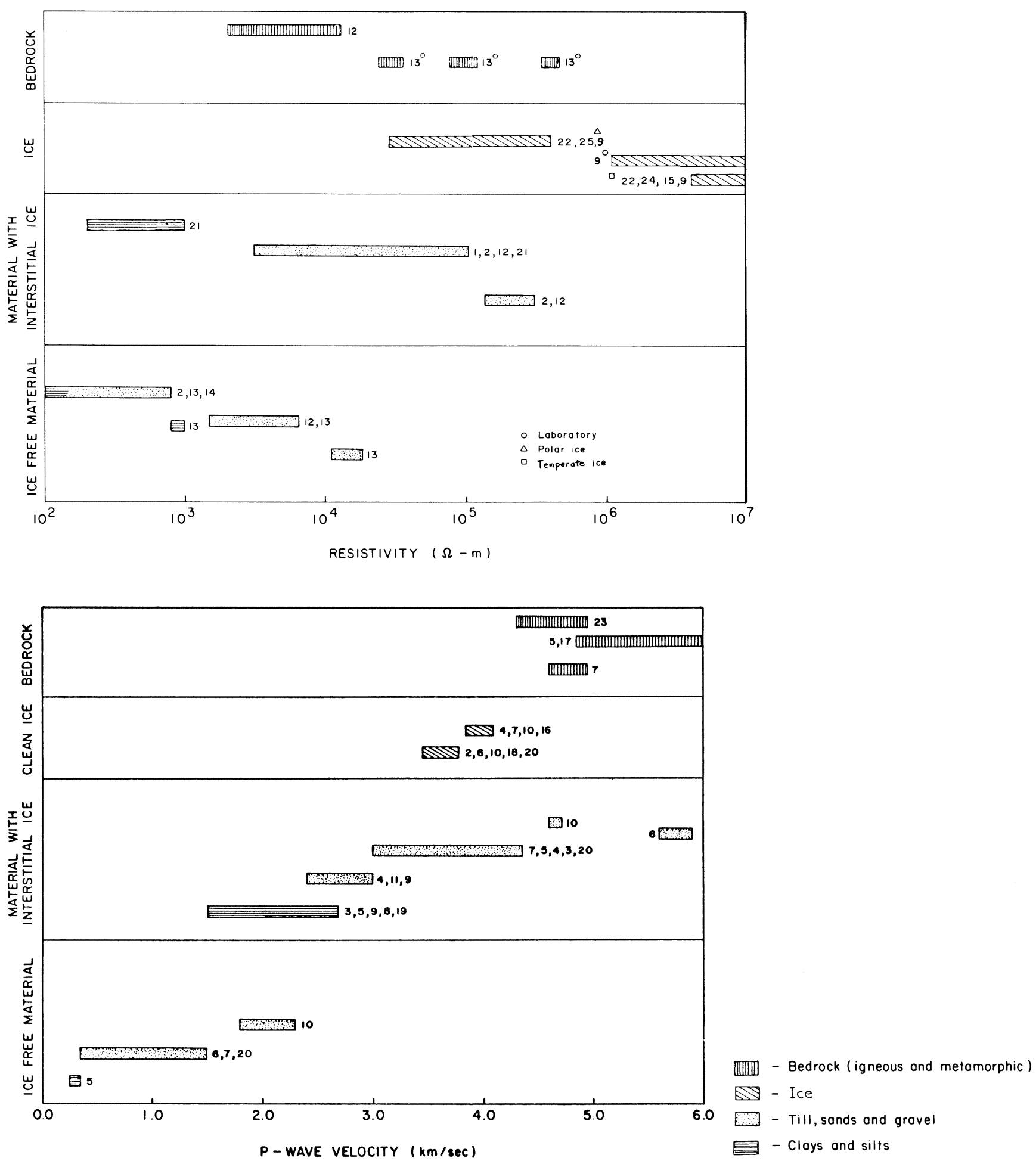

FiguRe 2. Electrical resistivities and $P$-wave velocities for sediments and bedrock typical of the study area. Sources: 1. Akimov (1978); 2. Bogolyubov (1978); 3. Dzhurik and Leshchikov (1978); 4. Voronkov and Mikhaylovskiy (1978); 5. Zykov and Baulin (1978); 6. McGinnis et al. (1973); 7. Bell (1966); 8. Thiokol (1964) cited in Bell (1966); 9. Reynolds and Paren (1980); 10. Röthlisberger (1972); 11. Potter (1972); 12. Fisch et al. (1977); 13. McGinnes and Jensen (1971); 14. Telford et al. (1976); 15. Röthlisberger and Vögtli (1967); 16. this study; 17. Barrett and Froggatt (1978); 18. Østrem (1964); 19. Hunter (1973); 20. Haeberli et al. (1979); 21. Larin et al. (1978); 22. Röthlisberger (1967); 23. Twomey (1968); 24. Vögtli (1967); 25. Meyer and Röthlisberger (1962); 26. Hochstein (1967). 
amount of subsurface information available from local bore holes (Mudrey et al., 1975), but also by information obtained from a literature search of geophysical studies in permafrost. Geophysical data derived from the literature are divided into four categories (Figure 2): icefree material, material with interstitial ice, ice, and bedrock.

Median values for the resistivity of ice-free sediment (Figure 2) are an order of magnitude less than most observations for material with interstitial ice and are several orders of magnitude less than the resistivity of polar ice (Figure 2). However, material with interstitial ice, ice, and bedrock are indistinguishable in the range of $5 \times 10^{4}$ to $5 \times 10^{5} \mathrm{ohm} \mathrm{m}$ if McGinnis and Jensen's (1971) laboratory measurements on bedrock are considered representative of field conditions.

Seismic $P$-wave velocities exhibit a more clearly defined trend (Figure 2) increasing from an average of $1.0 \mathrm{~km}$ for ice-free material (Bell, 1966; Röthlisberger, 1972; McGinnis et al., 1973; Zykov and Baulin, 1978) to $6.0 \mathrm{~km} \mathrm{~s}^{-1}$ for material with interstitial ice (Bell, 1966; Dzhurik and Leschikov, 1978; Haeberli et al., 1979). $P$ wave velocities for ice-free material and material with interstitial ice overlap in the range 1.5 to $2.4 \mathrm{~km} \mathrm{~s}^{-1}$ while bedrock, clean ice, and material with interstitial ice are seismically indistinguishable at $P$-wave velocities of $3.9 \mathrm{~km} \mathrm{~s}^{-1}$.

\section{DYNAMICS}

Rock glacier dynamics are inferred from morphological evidence as well as directly measured. Advancing and stagnant rock glaciers are commonly identified in temperate areas on the basis of morphological criteria (Wahrhaftig and Cox, 1959). These criteria include, for advancing features, termini at the angle of repose, free from vegetation, and at a sharp angle with the upper surface of the rock glacier. Conversely, stagnant rock glaciers usually have vegetation or lichen cover at their termini and/or have a terminus with a convex upward profile that gradually grades into the upper surface of the rock glacier. The only morphological indicator considered applicable in the Antarctic is that of a markedly convex shaped terminus since (1) the arid, polar climate severely restricts the growth of vegetation and (2) slopes at the angle of repose $\left(35\right.$ to $53^{\circ}$ ) (Shaw and Healy, 1977) can be maintained for longer periods of time in a polar climate than in a more temperate climate.

Movement studies consisted of analyses of the deformation of surficial material on four rock glaciers $(01,02$, 05,19 , Figures 3 and 4 ) as well as a detailed study of a three-dimensional movement network on one rock glacier (01). Rates of movement of surficial clasts were measured on photographs covering $1.5-\mathrm{km}^{2}$ areas (quadrapods) taken approximately $1 \mathrm{yr}$ apart. Five to 10 interclast distances were monitored and a minimum clast size of $10 \mathrm{~cm}$ was used to avoid clast movement from aeolian forces.

The flow regime of a single rock glacier (01, Figure 3) was studied in detail through analysis of a 12-yr record of movement data (Mayewski and Hassinger, 1980). The survey net consists of 15 wooden stakes inserted to an average depth of $50 \mathrm{~cm}$. Baseline distance was determined according to techniques specified by Bouchard and Moffitt (1965) using a calibrated, chrome-clad steel tape that was corrected for air temperature. Horizontal and vertical angles to the tops of survey stakes were measured with a DKM2 (Kern) theodolite and reduced by means of a computer program (Brecher, unpublished) utilizing standard bearing-bearing intersection equations (Bouchard and Moffitt, 1965). The magnitude and direction of principal strain rates are also derived by standard techniques (Jaeger, 1956) that describe observed deformation of strain rosettes consisting of groups of three survey stakes.

\section{RESULTS}

\section{Characteristics of Rock Glaciers}

Several trends in rock glacier characteristics can be generalized for the entire distribution (Figures 3 to 6). Rock glaciers range in length from 200 to $2600 \mathrm{~m}$ and areally from $5 \times 10^{4}$ to $10 \times 10^{6} \mathrm{~m}^{2}$ and total approximately $6 \%$ of the ice-free area of the valleys. Termini altitudes vary from 110 to $1140 \mathrm{~m}$ a.s.l., have vertical heights ranging from 6 to $25 \mathrm{~m}$, and are usually at the angle of repose $\left(35^{\circ}\right)$ (Shaw and Healy, 1977). Rock glaciers in cirques and those on talus walls are exclusively tongueshaped in contrast to the remaining settings which exhibit a variety of shapes (Figure 7). Surficial relief (other than patterned ground) such as transverse ridges and furrows, conical pits, and crevasses is found on only $20 \%$ of the rock glaciers and is not limited to a particular rock-glacier setting. Rock-glacier orientations are generally bimodal centering on north- and south-facing slopes (Figure 8). This distribution is principally attributed to the east-west orientation of Wright and Taylor valleys where $85 \%$ of the rock glaciers are found.

Common and diversified characteristics are also identified for each classification of rock glacier site. Rock glaciers found on talus walls (type $1 \mathrm{~b}$ ) comprise $21 \%$ of the total distribution and display little relief other than patterned ground. These rock glaciers also consist of a single lobe with a tongue shape and generally have the smallest areal extent of the groups measured, averaging $5.6 \times 10^{4} \mathrm{~m}^{2}$ (Figure 8). In contrast, rock glaciers at the base of talus slopes (type 1a) represent $31 \%$ of the sample population, exhibit a variety of shapes including lobate, tongue, and multiply lobed (Figure 7), and in general lack transverse ridges and furrows.

Rock glaciers found at cirque sites (type 2) comprise $48 \%$ of the total distribution, $24 \%$ of which are found below cirques (type 2b). Rock glaciers in cirques have tongue shapes (Figure 7) and areally range form $10^{5}$ to 
$10^{6} \mathrm{~m}^{2}$ (Figure 8). In contrast, rock glaciers found below cirques exhibit a variety of shapes (Figure 7) and show no relief other than polygonal ground. Rock glaciers whose heads grade into glaciers are of variable shape (Figure 7) and display ridges and furrows (rock glaciers 18,23 ) combined in one case (rock glacier 32 ) with conical

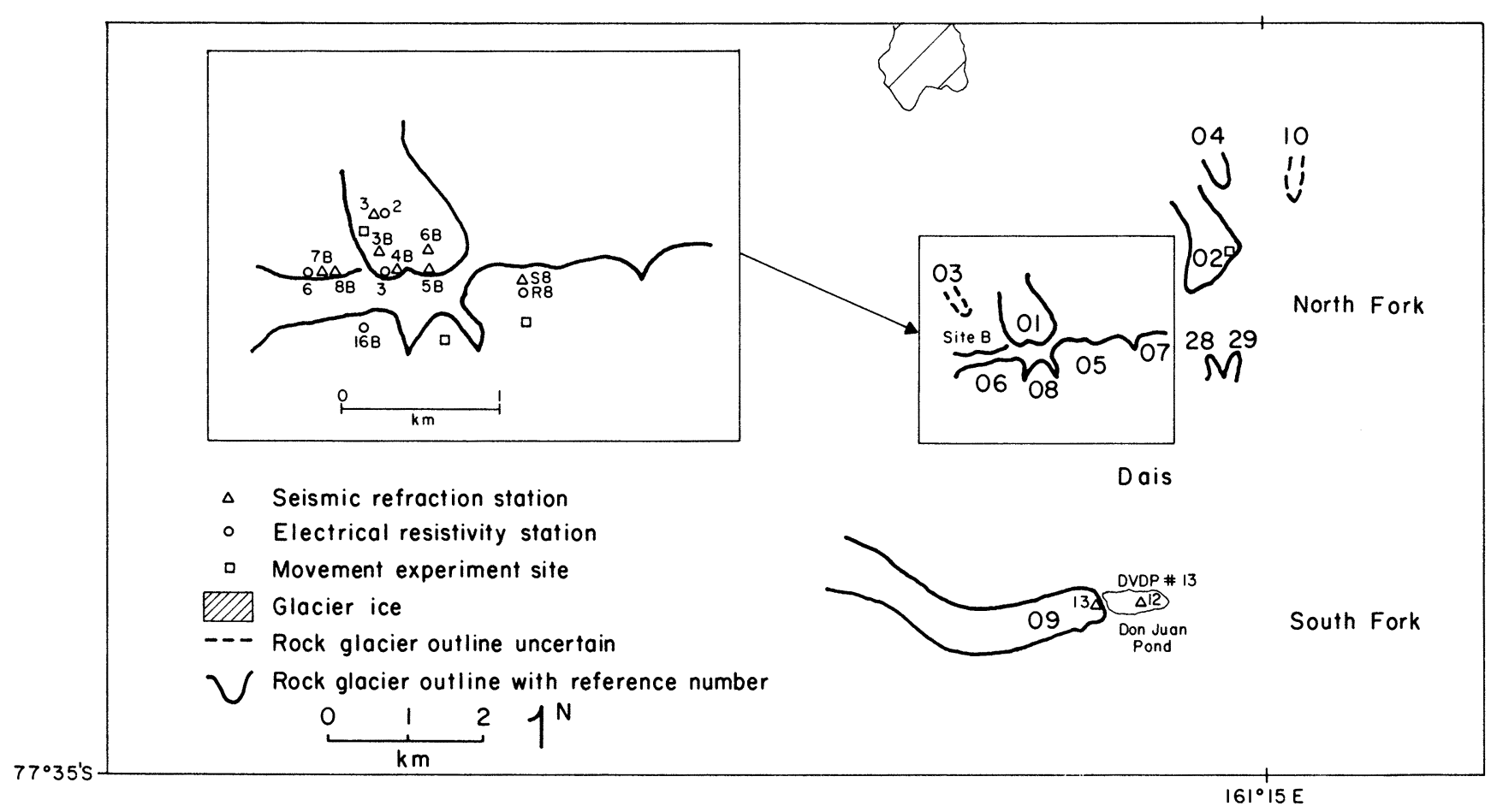

FIGURE 3. Map of rock glaciers in western Wright Valley (Figure 1, locs. 9 and 10) with the location of movement experiments and geophysical profiles (based on tracing from 1:50,000 topographic series, U.S. Geological Survey).

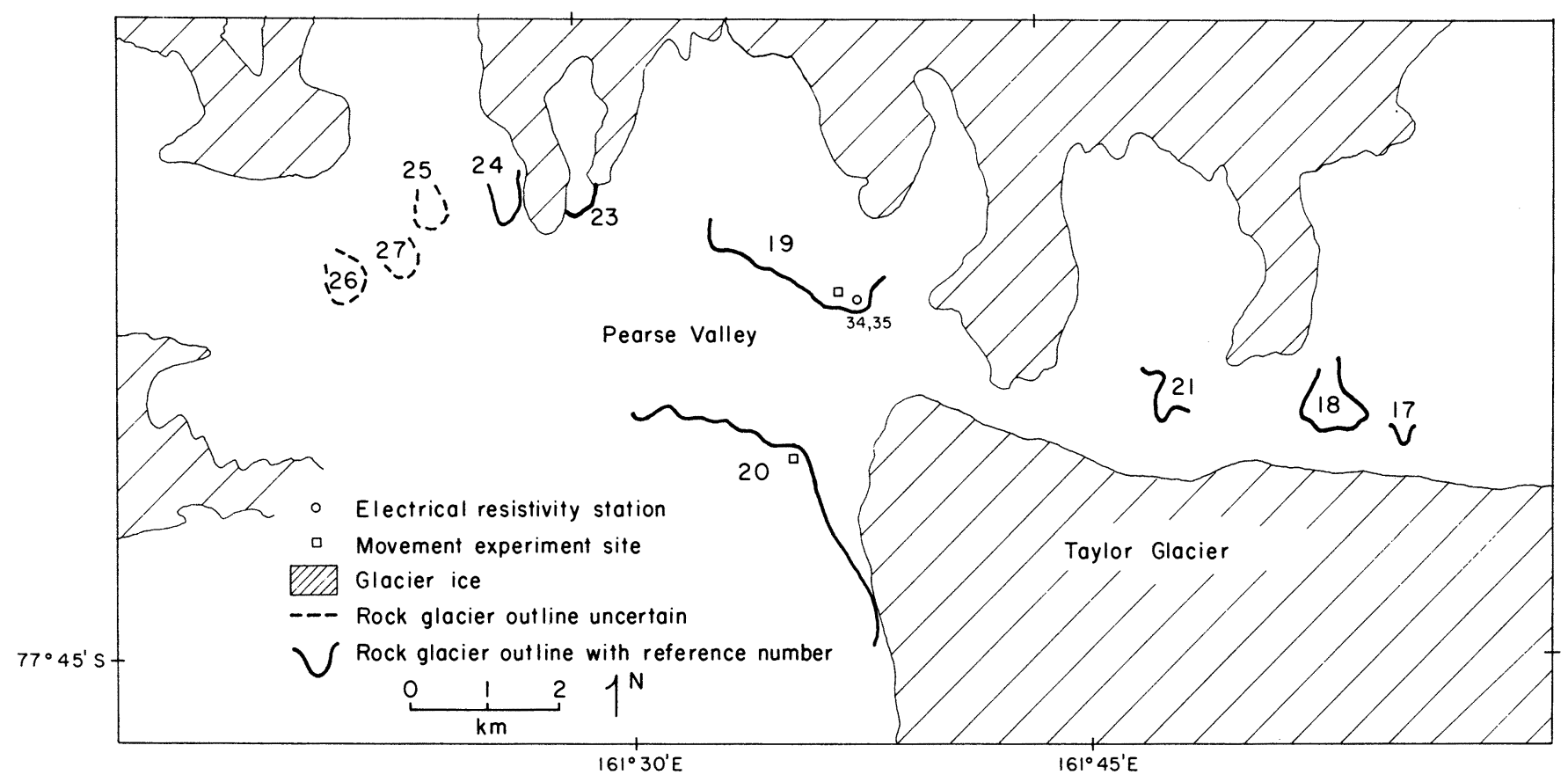

Figure 4. Map of rock glaciers in Pearse and upper Taylor valleys (Figure 1, loc. 7) showing the location of movement experiments and geophysical profiles (based on tracing from 1:50,000 topographic series, U.S. Geological Survey). 
pits. Rock glaciers at all three types of cirque settings were found to be approximately similar with regard to areal extent and lengths (Figure 8). The exceptional length of rock glacier $13(2600 \mathrm{~m}$, Figure 8$)$ is attributed to a greater than normal cirque length.

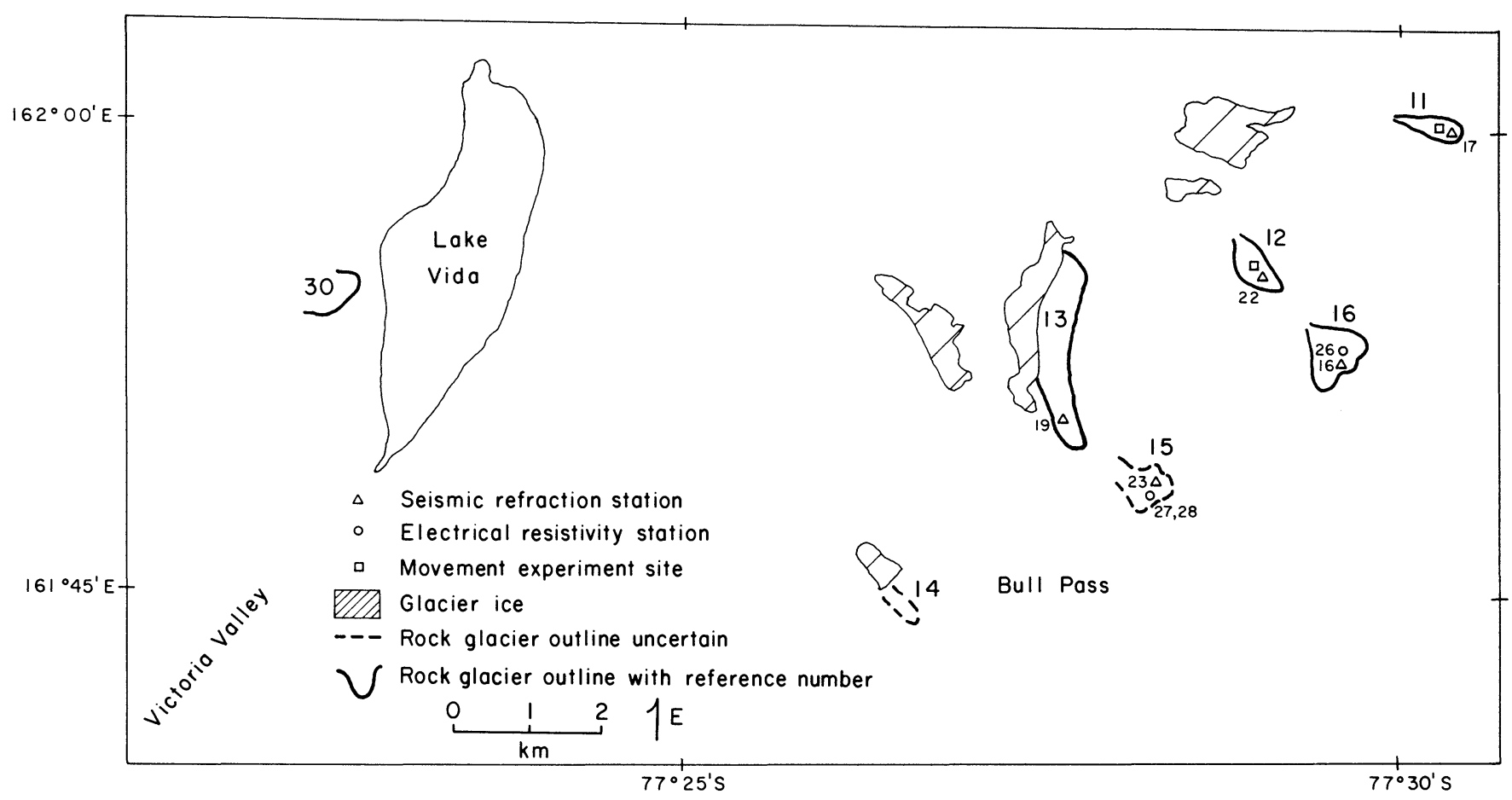

Figure 5. Map of rock glaciers in Bull Pass (Figure 1, loc. 6) and Victoria Valley showing the location of movement experiments and geophysical profiles (based on tracing from 1:50,000 topographic series, courtesy of U.S. Geological Survey).

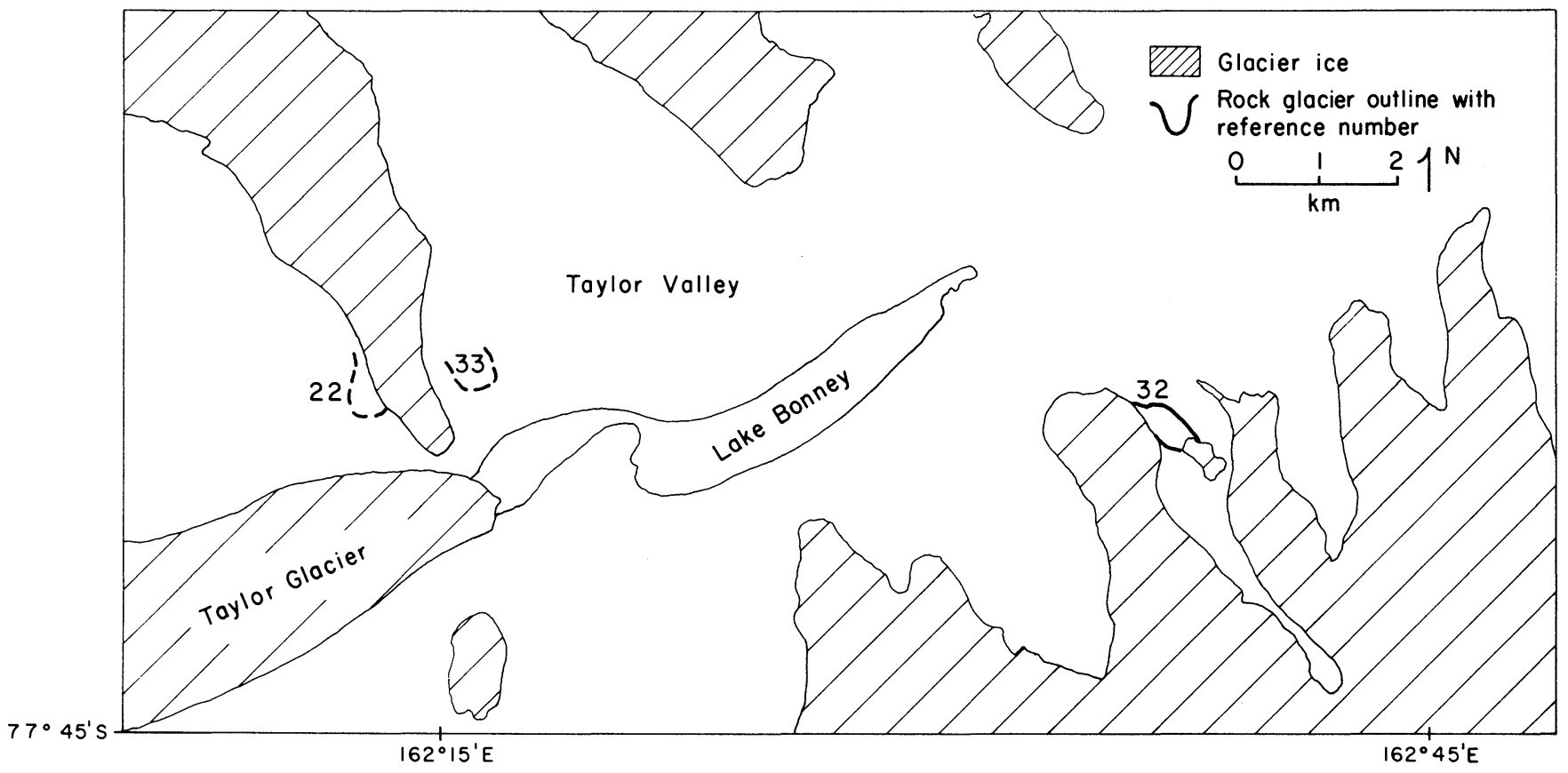

FiguRE 6. Map of rock glaciers in Taylor Valley (Figure 1, loc. 3) (based on tracing from 1:50,000 topographic series, U.S. Geological Survey). 
INFluence of ENVIRONMENTAL PARAmETERS ON RoCK GlaCIER DYNAMICS

Because they have a permafrost composition, temperature and moisture availability are the primary variables controlling rock glacier dynamics. Rock-glacier site altitude and incidence of solar radiation were investigated as the primary variables that control site temperature.

Rock glaciers at talus sites (type $1 \mathrm{a}$ and $1 \mathrm{~b}$ ) have southern orientations and range in altitude up to $1000 \mathrm{~m}$ (Figure 9). Surprisingly, talus rock glaciers with northern, and hence warmer, orientations are found at lower altitudes than those with southern orientations. Rock glaciers at cirque sites (type 2) have predominantly southern and western orientations. The higher frequency of these rock glaciers with southerly versus northerly orientations is believed due to the relatively lower amount of incident solar radiation that these slopes receive. The exclusive occurrence of rock glaciers at cirque sites with westerly orientations is not attributable to solar radiation since easterly and westerly orientations receive equal amounts.

Rock-glacier site temperature was further characterized by generating solar radiation curves (Figure 10) for azimuthal intervals of $30^{\circ}$ at $771 / 2^{\circ} \mathrm{S}$ latitude from a computer program available from Swift (1976). These curves conform with those calculated by McSaveney (1973) at Meserve Glacier in lower Wright Valley. Surprisingly, rock glaciers at talus settings and a limited number of rock glaciers at cirque settings occur at sites with northerly orientations and surface inclinations of 10 to $25^{\circ}$ and thus receive maximum amounts of incident radiation. However, these rock glaciers are also generally found in valley floors (altitudes $\leq 500 \mathrm{~m}$, Figure 11) where qualitative, on-site evaluation of shadow patterns indicates as much as $50 \%$ reduction of the calculated incident radiation by local topography. The remaining rock glaciers are at altitudes greater than $500 \mathrm{~m}$ (Figure 11) and occupy those sites that potentially receive the lowest amount of incident radiation $\left(115\right.$ to $\left.135 \mathrm{Kcal} \cdot \mathrm{cm}^{-2} \cdot \mathrm{yr}^{-1}\right)$. Thus, as might be expected, the amount of incident solar radiation at a rock glacier site is an influential control on rock glacier development.

The availability of moisture from local and regional sources was also evaluated as an important element in the development of rock glaciers. McMurdo Sound, lying to the east of the ice-free valleys, represents the regional

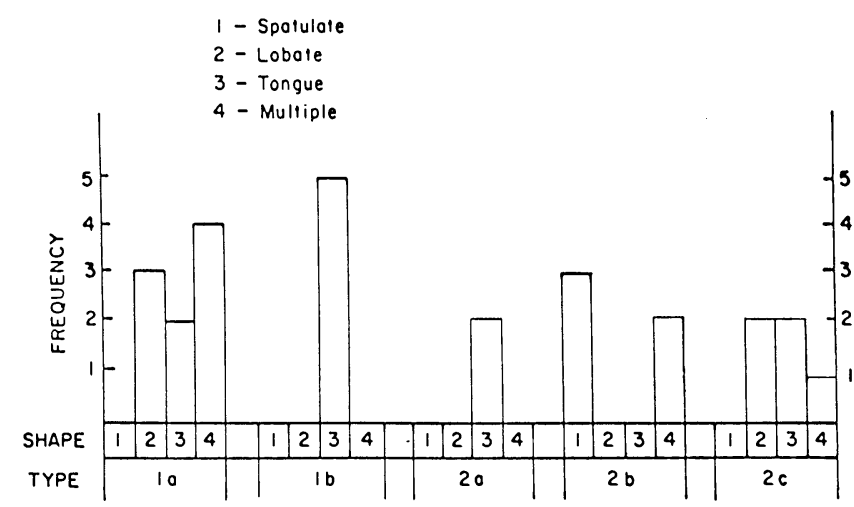

FIGURE 7. Frequency of rock glacier shape in different geomorphic settings. Type $1 \mathrm{a}-$ at the base of talus slopes; Type $1 \mathrm{~b}-$ on talus slopes; Type $2 \mathrm{a}-$ in cirques; Type $2 \mathrm{~b}$-below cirques; Type $2 \mathrm{c}-$ in transition with a glacier.

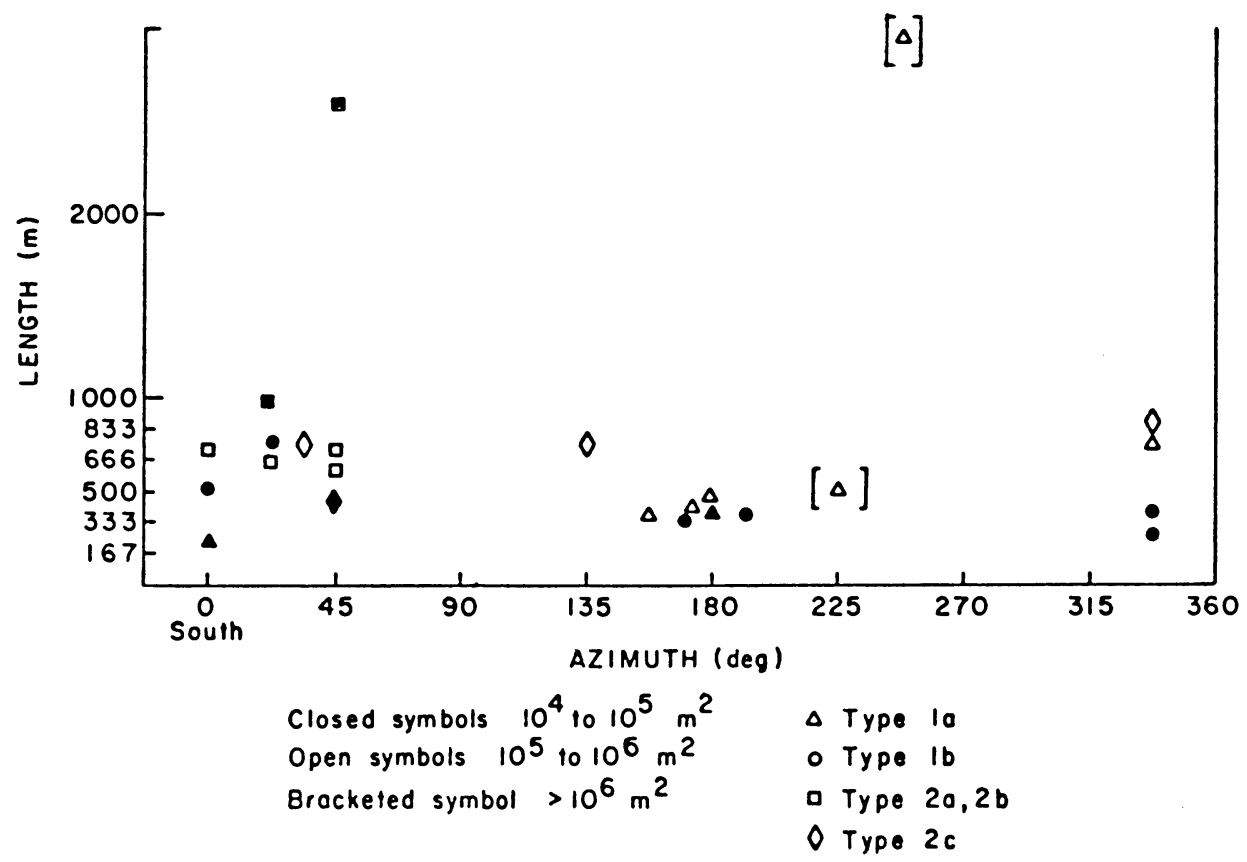

FIGURE 8. Dimensions and orientation of rock glaciers by type of geomorphic setting. Rock glacier orientation expressed as degrees azimuth, clockwise from south. Type 1a-at the base of talus slopes; Type $1 b-$ on talus slopes; Type $2 a$-in cirques; Type $2 b-$ below cirques; Type $2 c-$ in transition with a glacier. 


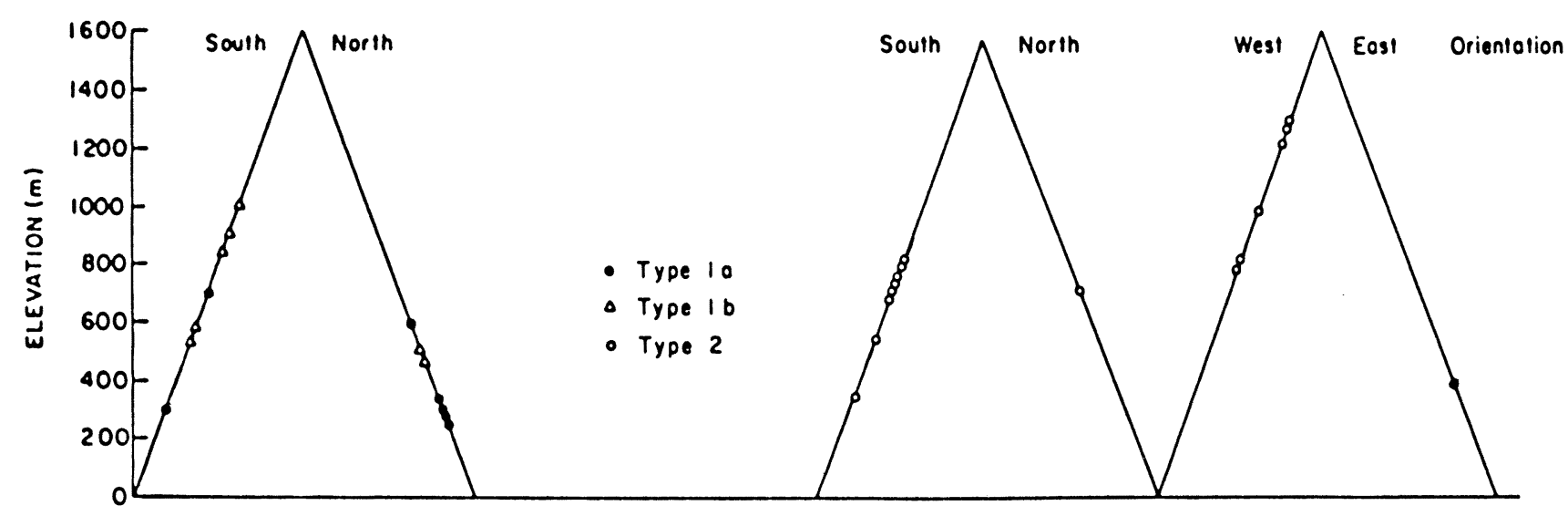

FIGURE 9. Variation of rock glacier head elevation and orientation by geomorphic setting. Type 1a, 1btalus sites; Type 2 -cirque sites.

moisture source for the study area. The western ends of the valleys are more arid as a result of their greater distance from the ocean and direct proximity to the relatively warm, dry katabatic winds that flow off the polar plateau. However, no correlation was found between the altitude of rock glacier sites and the decline in available moisture proceeding from McMurdo Sound to the more arid western portions of the valleys. The majority of rock glaciers are located in the drier western rather than eastern portions of the valleys at an average of 50 to $60 \mathrm{~km}$ from McMurdo Sound. However, $72 \%$ of the talus setting rock glaciers and all of the rock glaciers at cirque settings are associated with localized moisture sources. These sources are a glacier, a snowpatch, or stream channels at the head or on the surface of the rock glaciers.

Rock glacier sites are also characterized by geomorphic parameters that maximize the rate of debris supply to a rock glacier surface. For example, all rock glaciers are in proximity to bedrock-free faces that serve as debris sources. These sites also consistently occur below or adjacent to debris transport surfaces such as talus slopes that are at the angle of repose. Mass movement processes on slopes consist primarily of dry creep, aeolian activity, and rockfall. Field observations indicate the last process to be an infrequent, high-magnitude event. The influence of bedrock lithology and variations in jointing on the dynamics of rock glaciers is considered minimal since the two major lithologies, granite and dolerite, are found throughout the ice-free valleys.

\section{INTERNAL STRUCTURE}

Location and reference numbers for seismic refraction and electrical resistivity profiles completed in this study appear on Figures 3 to 6.

Rock glaciers are characterized by two to three geophysically detectable layers. The surface layer of rock glaciers $09,01,06,16$, and 15 ranges in thickness from 0.5 to $1.4 \mathrm{~m}$ and is characterized by $P$-wave velocities ranging from 0.26 to $0.9 \mathrm{~km} \mathrm{~s}^{-1}$ and resistivities of $6 \times 10^{2}$ to $8 \times 10^{3} \mathrm{ohm} \mathrm{m}$. These geophysical data are interpreted
(Figure 12) as representing ice-free material. Similar seismic velocities averaged for the surface layer of rock glaciers $11,12,13$, and 05 also fall within ranges defined for ice-free material (Figure 13). Shallow $(<1 \mathrm{~m})$ excavations in the upper layer of all of the rock glaciers revealed unconsolidated sands and silts with varying percentages of cobbles.

A second refractor is inferred from geophysical evidence at $45 \%$ of the features. Rock glaciers 15, 16 (Figure 12; open triangles) are inferred to have a refractor 1.5 to $4.6 \mathrm{~m}$ thick, that exhibits $P$-wave velocities of approximately $2.9 \mathrm{~km} \mathrm{~s}^{-1}$ and resistivities ranging from $2 \times 10^{2}$ to $5 \times 10^{3} \mathrm{ohm} \mathrm{m}$. These geophysical parameters fall within the range of interstitially frozen mate-

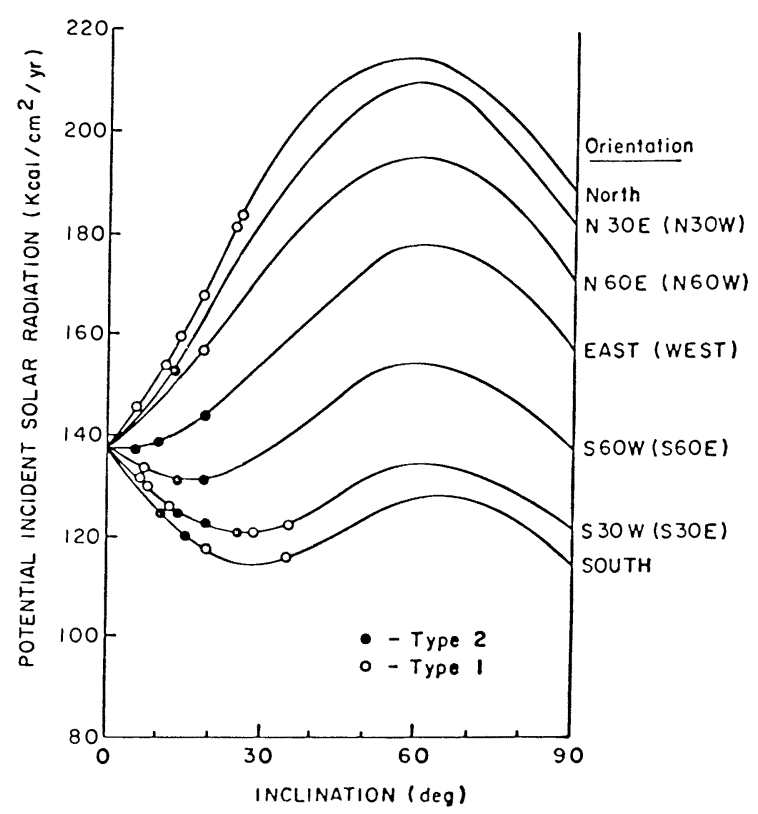

FIGURE 10. Incident solar radiation on slopes with various inclinations and orientations. Type 2 -associated with cirque settings; Type 1 -associated with talus settings. 
rial (Figure 12). Unfortunately, resistivity soundings on rock glacier (01) for which a similar refractor was seismically defined (Figure 13) yielded erratic data that precluded meaningful interpretation. Finally, an ice-free composition is indicated (Figure 13) by $P$-wave velocities of $1.2 \mathrm{~km} \mathrm{~s}^{-1}$ for the second refractor on rock glacier 11 .

While a third refractor is identified at all of the rock glaciers, a unique composition is geophysically defined at only rock glacier 11 (Figure 13; ice-free material) and rock glaciers 15 (Figure 12) and 06 and 05 (Figure 13; material with interstitial ice). Geophysical data for this lower refractor on the remaining rock glaciers fall within polycompositional zones that include material with interstitial ice or ice $(12,13,09$, Figure 13), bedrock, ice, or interstitially frozen material (01, 095, Figure 13), or ice, and/or bedrock (16, Figure 12).

Patterns of relief at the surface of rock glaciers were also examined as evidence of an internal ice core. Morphological criteria including (1) spoon-shaped depressions located between the head of a rock glacier and ablating, exposed ice, (2) looping ridges immediately downslope from the rock glacier, and (3) conical melt-out pits have been used as indicators of an ice core within rock glaciers (Outcalt and Benedict, 1965; White, 1976; Ellis and Calkin, 1979). Three rock glaciers $(12,13,32$; Figures 5 and 6) closely exhibit one or more of these characteristics. The presence of an internal ice core for these rock glaciers is further evidenced by ice encountered beneath 0.5 to $0.6 \mathrm{~m}$ of blocky debris in surface excavations. Rock glaciers of type 1 (talus) variety whose internal compositions were nonuniquely defined by geophysical data $(01$, $05,09)$ fail to display any features indicative of an ice core and are not presently near glaciers that could serve as clean ice sources. Therefore, these rock glaciers are inferred to have cores of interstitially frozen debris.

\section{DYNAMICS}

The dynamics of the two major geophysically defined layers, a lower layer comprised of ice or interstitially frozen debris and an upper ice-free layer, were directly measured and indirectly inferred from morphological criteria. These units are considered separately in this analysis since their dynamics, and hence responsiveness, are functioins of their differing compositions.

Results from monitoring of a movement network on rock glacier 01 serve to quantify rates of movement for the inferred interstitially frozen debris core of this rock glacier. Horizontal and vertical displacements for 5 of 13 survey stakes (Table 1) reflect the movement of the core of the rock glacier since their insertion depth exceeds the thickness of the upper ice-free layer as determined from geophysical soundings and shallow pits. Downslope displacements induced by rotation of the survey stakes are below measurement precision $\left( \pm 5^{\circ}\right)$. Thus, observed horizontal displacements can be directly converted into horizontal velocities. Positive velocities are measured downslope and upwards away from the rock glacier surface.

Horizontal velocities (Table 1) measured for the internal portion of rock glacier 01 reach a maximum of $3.3 \mathrm{~cm} \mathrm{yr}^{-1}\left( \pm 0.8 \mathrm{~cm} \mathrm{yr}^{-1}\right)$ at stake 4 near the upper portion of the rock glacier (Figure 14). Velocities of the lower stakes $(9,10)$ are unresolvable since they are below the precision of the measurement technique $( \pm 0.5-$ $\left.0.6 \mathrm{~cm} \mathrm{yr}^{-1}\right)$. Vertical velocities $\left(V_{z}\right)$ are equivalent to lowerings of 0.04 to $1.4 \mathrm{~cm} \mathrm{yr}^{-1}$ ) (Table 1). Measured horizontal velocities for this rock glacier (01) are only comparable with the lowest values reported for rock glaciers in the Swiss Alps (3 to $238 \mathrm{~cm} \mathrm{yr}^{-1}$ ) (Barsch and Hell, 1975, cited in Washburn, 1980) and are well below those measured by Wahrhaftig and Cox (1959) in Alaska (36 to $69 \mathrm{~cm} \mathrm{yr}^{-1}$ ).

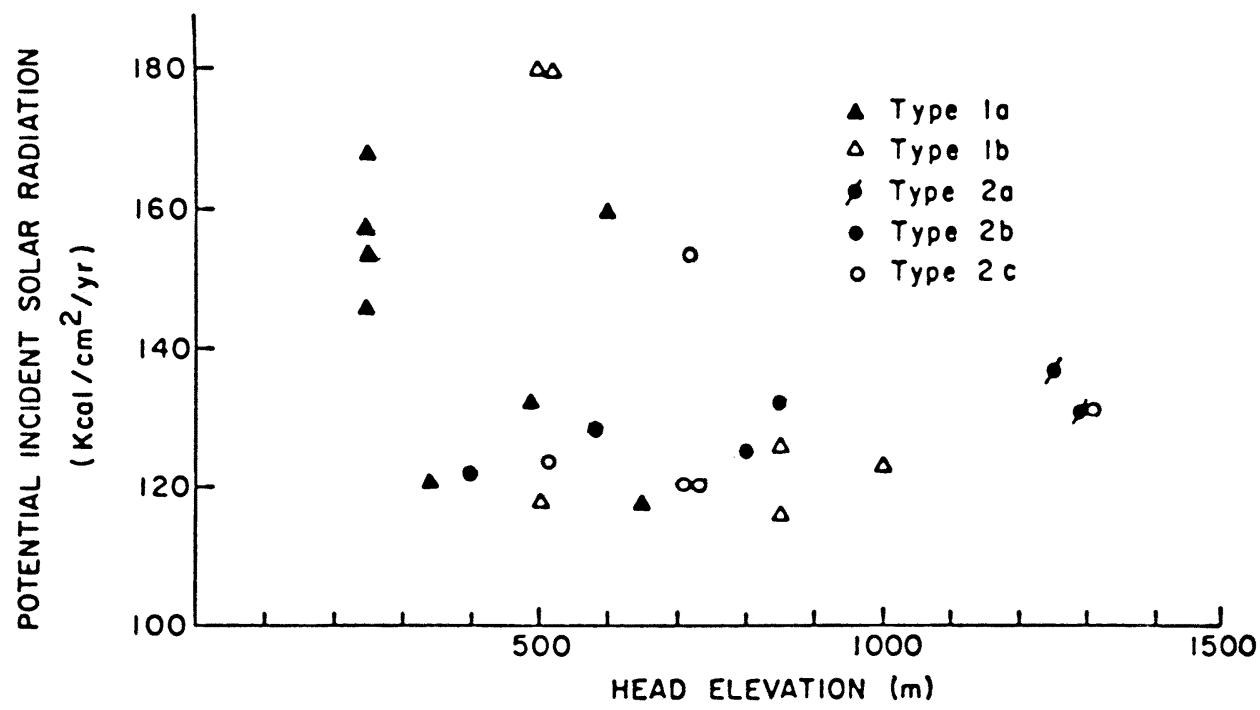

FIGURE 11. Potential incident solar radiation versus elevation of rock glacier head elevations. Type 1a-at the base of talus slopes; Type $1 \mathrm{~b}$-on talus slopes; Type $2 \mathrm{a}$-in cirques; Type $2 \mathrm{~b}$-below cirques; Type $2 \mathrm{c}-$ in transition with a glacier. 


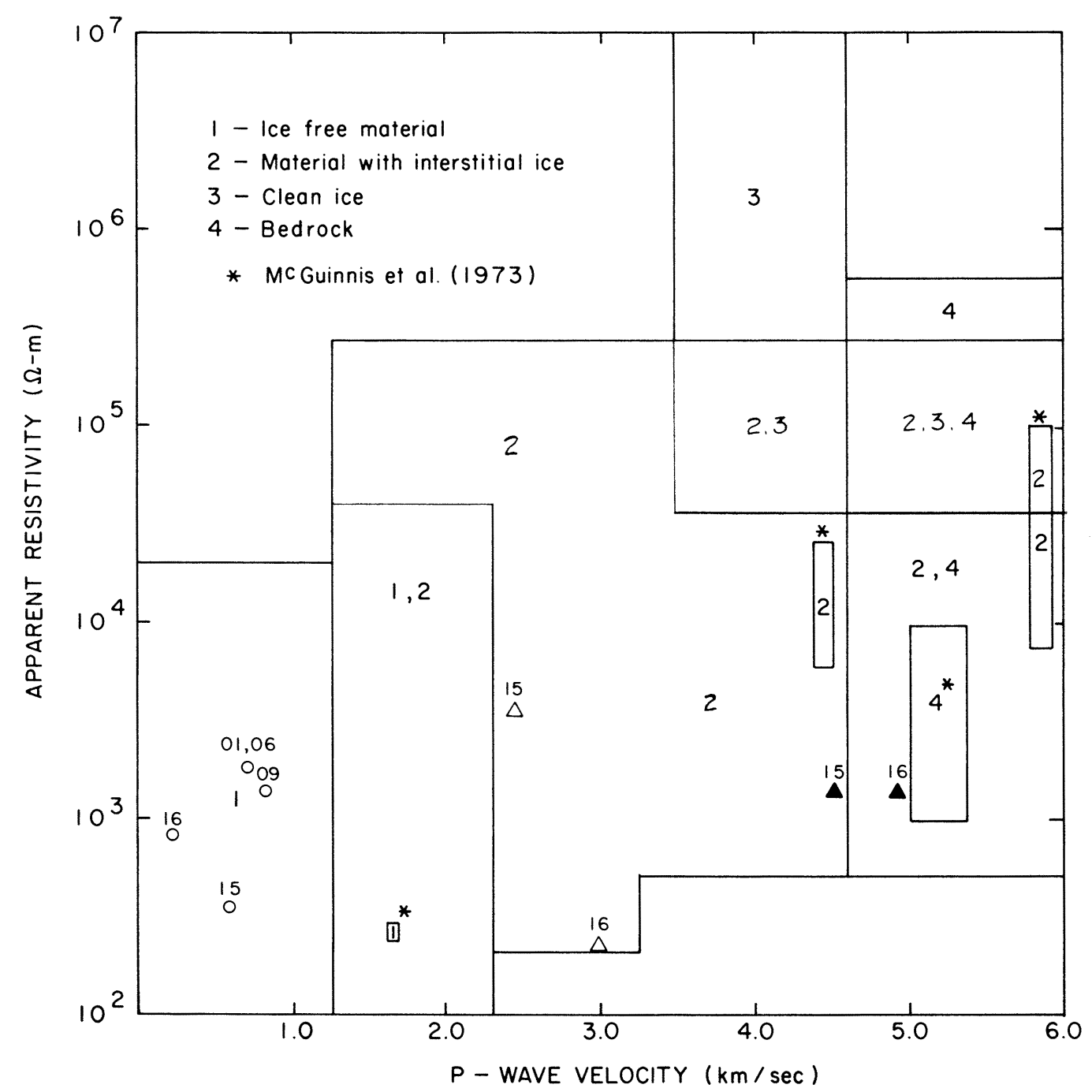

FIGURE 12. Compositional interpretation for layers defined by electrical resistivity and seismic wave velocity data.

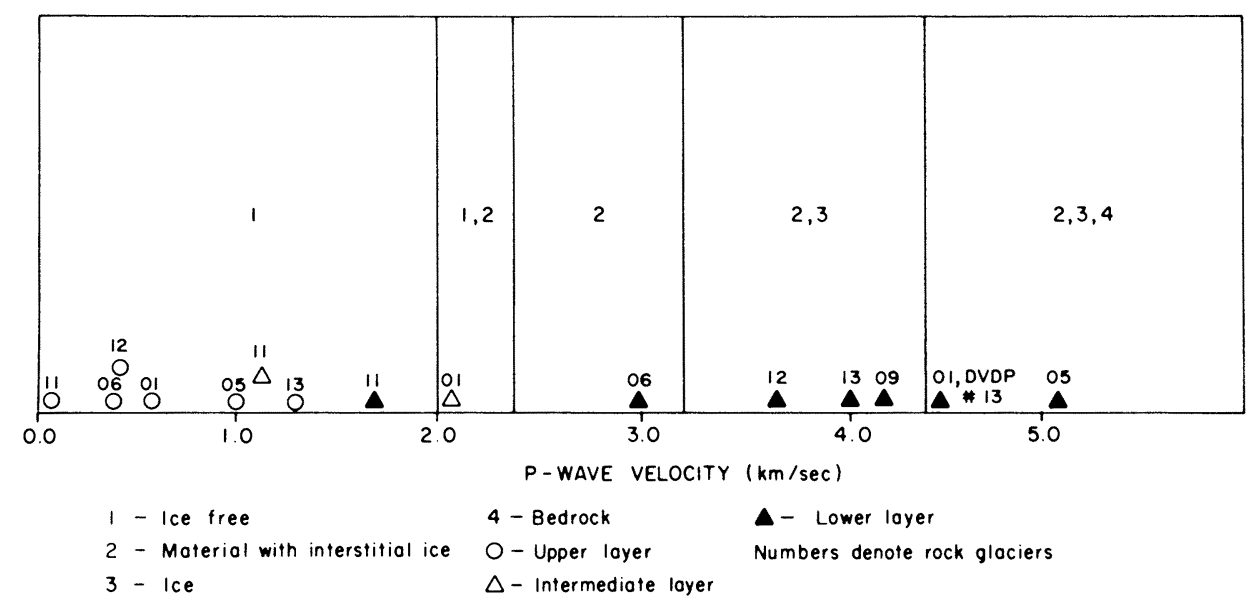

FIGURE 13. Compositional interpretation of layers for which $P$-wave velocity data were collected.

J. M. Hassinger and P. A. Mayewski / 361 
The deformation of the lower layer of rock glacier 01 can be further quantified by using stakes 4,5 , and 6 as a strain rosette from which principal strain rates are measured. A compressive component $\left(\epsilon_{2}\right)$ with a magnitude of $-9.98 \times 10^{-4} \mathrm{yr}^{-1}$ and an extensional component $\left(\epsilon_{1}\right)$ of $3.22 \times 10^{-4} \mathrm{yr}^{-1}$ were measured for the 9.95-yr observation period. The secondary axis of strain $\left(\epsilon_{2}\right)$ is aligned (Figure 14) at $-18^{\circ}$ to the $y$-axis of the survey baseline. This direction is approximately normal to the west edge of the rock glacier and is inferred to be parallel to the flowline of this portion of the rock glacier on the basis of measured survey stake velocities. Measured strain rates are comparable with the lower range of longitudinal strain measured by Haeberli et al. (1979) of $10^{-2}$ to $10^{-4} \mathrm{yr}^{-1}$ on rock glaciers in the Swiss Alps. Movement experiments on five additional rock glaciers $(5,11,12,19,20)$ are expected to yield similar data on the deformation of their internal cores when remeasured in approximately $5 \mathrm{yr}$.

The movement of the upper, ice-free layer of a rock glacier is reflected by the intensity of surficial processes such as dry creep and the growth of sorted and nonsorted frost wedges. Quantitative modeling of these processes is complex, since it involves detailed observation of a variety of microclimatic, geomorphic, and thermodynamic variables over long observation periods (Black, 1973). However, the relative activity of surficial material can be approximated by measurement of change in interclast distances and from the survey of stake networks on the surfaces of the rock glaciers.

Results from quadrapod measurements on four rock glaciers are summarized in Table 2 . Changes in interclast distances that exceeded the precision of the measurement technique (values with asterisks, Table 2) are of uniform magnitude at two quadrapod sites (QS): QS 06 on rock glacier 02 and QS 14 on rock glacier 01 . Displacements of 1 to $2 \mathrm{~cm}$ measured at QS 06 are believed due to the growth of sorted frost wedges adjacent to the site and to downslope movement of the clasts by dry creep. However, dry creep is believed to be the dominant process at QS 14 since this area is devoid of frost wedges. Thus, the changes in interclast distances at QS 14 may be used to define a minimum downslope creep velocity in this area of approximately $1 \mathrm{~cm} \mathrm{yr}^{-1}$ provided it is assumed that all displacements occur in a downslope direction. Finally, the occurrence of the majority of the data in the range $\leq 0.6 \mathrm{~cm}$ serves to emphasize that observation periods in excess of $1 \mathrm{yr}$ are necessary to define more quantitatively the activity of the surficial material of these rock glaciers.

The relative rate of deformation of surficial material versus the internal core of a rock glacier is also inferred from the height of a talus apron at its terminus. Rock glaciers examined in this study have two distinctly different terminal morphologies with $19 \%$ of the entire distribution (Table 3 ) having $\geq 80 \%$ of their frontal height covered by talus. In contrast, $28 \%$ have talus aprons extending $<20 \%$ of the height of their termini.

Rock glacier terminal morphology is also used to identify stagnant features. Criteria considered indicative of rock glaciers that are no longer advancing are differences in morphology and calculated shear stress levels that are below the minimum 1 bar specified by Wahrhaftig and Cox (1959) for rock glaciers with an actively deforming core. Thirty-eight percent of the rock glaciers in this study display convex-upward terminal profiles (Table 3 ) and are using criteria defined by Wahrhaftig and Cox (1959) considered stagnant; however, $30 \%$ of these rock glaciers also have shear stress values that are not significantly less than 1 bar. Furthermore, shear stress values calculated for four rock glaciers that fail to display convex-upward terminal profiles (Table 3) also fail to occur significantly above 1 bar. Clearly, refinement in the use of shear stress as an indicator of rock glacier activity is required.

Flow regimes, modified from those developed by Wahrhaftig and Cox (1959), that allow maintenance of the frontal profile of rock glaciers at the angle of repose are used to explain the observed variations in the heights of talus aprons. Movement resulting from basal slippage is considered a negligible component in the flow regimes of these rock glaciers since even true glaciers in the icefree valleys are believed frozen to their beds (Calkin, 1971). A model having movement of a mobile surface layer over a relatively stable interior and velocity decreasing rapidly with depth is used to explain termini with talus aprons that extend $\geq 80 \%$ of the terminal height. A model in which velocity gradually decreases with depth is used to explain rock glacier termini that have a talus apron $\leq 20 \%$ of the total terminal height.

TABLE 1

Summary of three-dimensional movement data for rock glacier 01 for the period 1971 to 1980

\begin{tabular}{cccccc}
\hline \hline $\begin{array}{c}\text { Stake } \\
\text { number }\end{array}$ & $\begin{array}{c}\text { Insertion } \\
\text { depth } \\
(\mathrm{cm})\end{array}$ & $\begin{array}{c}\text { Horizontal } \\
\text { displacement }(\mathrm{cm}) \\
( \pm 3.0 \mathrm{~cm})\end{array}$ & $\begin{array}{c}\text { Vertical } \\
\text { displacement }(\mathrm{cm}) \\
( \pm 2.0 \mathrm{~cm})\end{array}$ & $\begin{array}{c}\text { Horizontal } \\
\text { velocity } \\
\left(\mathrm{cm} \mathrm{yr}^{-1}\right)\end{array}$ & $\begin{array}{c}\text { Velocity } \\
\text { perpendicular to } \\
\text { rock glacier } \\
\left(\mathrm{cm} \mathrm{yr}^{-1}\right) \pm\left(0.22 \mathrm{~cm} \mathrm{yr}^{-1}\right)\end{array}$ \\
\hline 4 & 43 & 33.2 & -10.9 & $3.3 \pm 0.8$ & -0.22 \\
5 & 31 & 12.3 & -16.8 & $1.2 \pm 0.8$ & -1.4 \\
6 & 36 & 15.4 & -8.2 & $1.5 \pm 0.8$ & -0.44 \\
9 & 62 & 2.2 & -0.2 & $0.22 \pm 0.5$ & -0.04 \\
10 & 56 & -6.0 & -1.6 & $-0.60 \pm 0.6$ & 0.00 \\
\hline
\end{tabular}




\section{SUMMARY AND DISCUSSION}

The development of rock glaciers in the ice-free valleys is shown to be more dependent on site specific variables than regional geologic or climatic trends. Site specific variables that control the formation and preservation of ice at a rock glacier site include elevation, orientation, topographic shading, and proximity to local moisture sources. Microclimatic variables that control the development of ice at a rock glacier site are considered to be the most influential in rock glacier development and activity, since a large number of sites with the necessary geomorphic conditions do not presently contain rock glaciers. However, causes of observed responses of rock glaciers must be understood if rock-glacier dynamics are to be interpreted in the context of climatic change.

The dynamics of the upper ice-free layer and lower layers of rock glaciers comprised of interstitially frozen debris or glacier ice differ and hence are examined separately.

The activity of the upper ice-free layer is a function of the intensity of surface processes that include dry creep and the formation of ice-wedge polygons (Calkin, 1964; Black, 1973). However, dry creep of surficial material can be identified as the dominant process for rock glaciers with actively deforming surface layers since this situation commonly prevents the development of ice wedges.

Theoretical models developed by Scheidegger (1970) serve as a method for quantitatively relating observed or inferred changes in the dry creep rate to climatic and nonclimatic causal mechanisms (Table 4). Downslope displacement $\left(S_{T}\right)$ of a particle, undergoing unconstrained expansion during a temperature cycle is given in this model by:

$$
S_{T}(h)=x h f(\phi)\left(\frac{1}{\tan \phi-\tan \beta}\right) e^{-m h}\left(\delta T_{0}\right)
$$

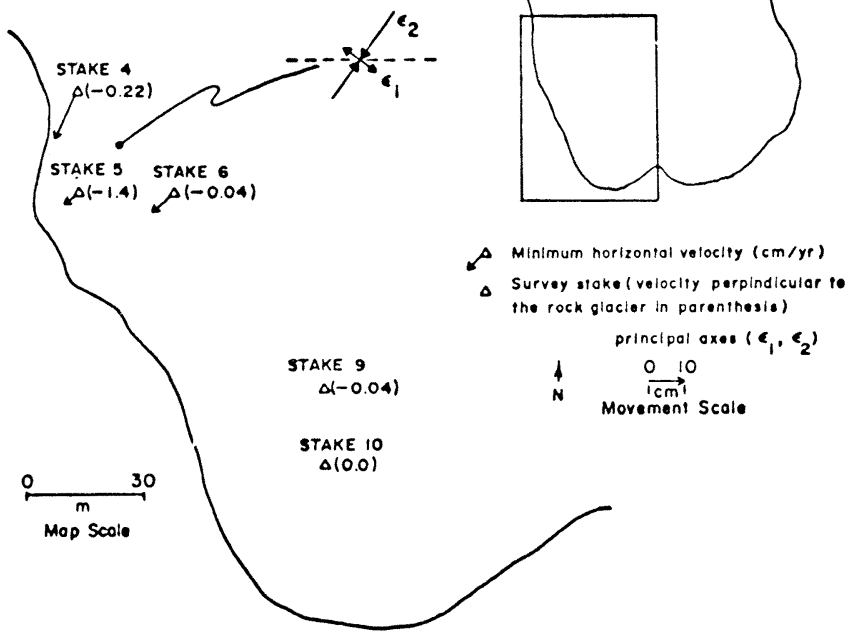

TABLE 2

Summary of results from quadrapod experiments

\begin{tabular}{|c|c|c|c|}
\hline \multirow{2}{*}{$\begin{array}{c}\text { Rock } \\
\text { glacier } \\
\text { number }\end{array}$} & \multirow{2}{*}{$\begin{array}{c}\text { Quadrapod } \\
\text { site } \\
\text { number }\end{array}$} & \multicolumn{2}{|c|}{$\begin{array}{l}\text { Change in interclast distance }(\mathrm{cm}) \\
\text { over 1-yr period }( \pm 0.6 \mathrm{~cm})\end{array}$} \\
\hline & & Downslope & $\begin{array}{l}\text { Transverse } \\
\text { to slope }\end{array}$ \\
\hline \multirow[t]{8}{*}{05} & 05 & $2.1^{* \mathrm{a}}$ & \\
\hline & & 0.2 & \\
\hline & & 0.3 & \\
\hline & & $1.1^{*}$ & \\
\hline & & 0.5 & \\
\hline & 03 & 0.1 & $0.9^{*}$ \\
\hline & & $1.6^{*}$ & 0.4 \\
\hline & & 0.6 & \\
\hline \multirow[t]{11}{*}{02} & 06 & $2.0^{*}$ & 0.6 \\
\hline & & $1.3^{*}$ & $0.8^{*}$ \\
\hline & & $1.4^{*}$ & \\
\hline & 08 & $1.4^{*}$ & 0.2 \\
\hline & & 0.0 & 0.4 \\
\hline & & 0.1 & \\
\hline & & 0.4 & \\
\hline & 07 & 0.4 & 0.3 \\
\hline & & 0.3 & \\
\hline & & 0.4 & \\
\hline & & $1.3^{*}$ & \\
\hline \multirow[t]{18}{*}{01} & 10 & $0.8^{*}$ & 0.6 \\
\hline & & $0.9^{*}$ & $0.7^{*}$ \\
\hline & & 0.2 & 0.5 \\
\hline & & 0.4 & \\
\hline & 09 & 0.0 & 0.3 \\
\hline & & 0.1 & 0.1 \\
\hline & & 0.5 & 0.0 \\
\hline & & 0.3 & \\
\hline & 14 & $0.8^{*}$ & 0.2 \\
\hline & & $1.1^{*}$ & 0.3 \\
\hline & & $1.2^{*}$ & $0.7^{*}$ \\
\hline & & $0.9^{*}$ & \\
\hline & 05 & 0.6 & 0.4 \\
\hline & & $1.1^{*}$ & 0.3 \\
\hline & & $1.2^{*}$ & 0.0 \\
\hline & & 0.4 & 0.2 \\
\hline & & $0.7^{*}$ & \\
\hline & & 0.1 & \\
\hline \multirow[t]{8}{*}{19} & 05 & 0.6 & 0.3 \\
\hline & & 0.6 & 0.1 \\
\hline & & 0.5 & \\
\hline & & 0.1 & \\
\hline & 07 & 0.2 & \\
\hline & & 0.1 & \\
\hline & & 0.0 & \\
\hline & & 0.2 & \\
\hline
\end{tabular}

${ }^{\mathrm{a} A s t e r i s k s ~ d e n o t e ~ d a t a ~ a b o v e ~ m e a s u r e m e n t ~ p r e c i s i o n . ~}$

FIGURE 14. Diagrammatic sketch of magnitudes and directions of flow parameters measured for the internal core of rock glacier 01 . 
TABLE 3

The activity of the internal core of rock glaciers as inferred from indirect evidence

\begin{tabular}{|c|c|c|c|c|c|}
\hline $\begin{array}{c}\text { Rock } \\
\text { glacier } \\
\text { number }\end{array}$ & $\begin{array}{c}\text { Extent } \\
\text { talus apron } \\
H=\geq 80 \% \\
L=\leq 20 \% \\
\text { of toe height }\end{array}$ & $\begin{array}{l}\text { Frontal crest } \\
\text { height }(H F) \\
( \pm 2.5 \mathrm{~m})\end{array}$ & $\begin{array}{l}\text { Surface slope } \\
\text { angle }(A) \\
\left( \pm 5^{\circ}\right)\end{array}$ & $\begin{array}{c}\text { Thickness } \\
\begin{array}{c}(H)=H F \cos A \\
( \pm 2.4 \mathrm{~m})\end{array}\end{array}$ & $\begin{array}{l}\text { Shear } \\
\text { stress } \\
\text { (bars) }\end{array}$ \\
\hline \multicolumn{6}{|c|}{ Rock glaciers with terminal profiles at the angle of repose } \\
\hline $\begin{array}{l}01 \\
04 \\
10 \\
17 \\
18 \\
22 \\
28 \\
29 \\
33\end{array}$ & $\begin{array}{l}L \\
L \\
L \\
L \\
L \\
L \\
L \\
L \\
L\end{array}$ & 20.0 & 15 & 19.3 & $0.88 \pm 0.28$ \\
\hline 03 & $H$ & & & & \\
\hline 05 & $H$ & 18.0 & 15 & 17.4 & $0.79 \pm 0.26$ \\
\hline $\begin{array}{l}08 \\
14\end{array}$ & $\begin{array}{l}H \\
H\end{array}$ & 20.0 & 20 & 18.8 & $1.1 \pm 0.27$ \\
\hline $\begin{array}{l}20 \\
32\end{array}$ & $\begin{array}{l}H \\
H\end{array}$ & 15.0 & 20 & 14.5 & $0.85 \pm 0.21$ \\
\hline \multicolumn{6}{|c|}{ Rock glaciers with convex-upward terminal profiles } \\
\hline 02 & & 15.0 & 15 & 14.5 & $0.66 \pm 0.20^{* b}$ \\
\hline 06 & & 18.0 & 10 & 17.8 & $0.49 \pm 0.27 *$ \\
\hline 07 & & 20.0 & 15 & 10.3 & $0.88 \pm 0.28$ \\
\hline 09 & & 17.0 & 15 & 16.4 & $0.75 \pm 0.24$ \\
\hline 11 & & 20.0 & 15 & 19.3 & $0.88 \pm 0.28$ \\
\hline 12 & & 15.0 & 20 & 14.1 & $0.85 \pm 0.20$ \\
\hline 13 & & 6.0 & 10 & 5.9 & $0.18 \pm 0.091^{*}$ \\
\hline 15 & & $<20.0$ & 9 & 19.2 & $\leq 0.54 \pm 0.30^{*}$ \\
\hline 16 & & 15.0 & 15 & 14.5 & $0.66 \pm 0.21^{*}$ \\
\hline 19 & & 10.0 & 9 & 9.8 & $0.27 \pm 0.15^{*}$ \\
\hline 27 & & 5.0 & $<20$ & 4.7 & $\leq 0.28 \pm 0.068^{*}$ \\
\hline 30 & & 10.0 & 9 & 9.8 & $0.27 \pm 0.15^{*}$ \\
\hline
\end{tabular}

${ }^{a}$ Terminal data unavailable for rock glaciers $21,23,24,25$, and 26.

${ }^{\mathrm{b}}$ Asterisks denote shear stress values $<1$ bar within calculated precisions.

TABLE 4

Idealized causal mechanisms for rock glacier responses in the ice free valleys

\begin{tabular}{lll}
\hline \hline Ice-free upper layer & Response & \multicolumn{1}{c}{ Causal mechanism } \\
\hline Internal "core" & Decline in horizontal velocity & $\begin{array}{l}\text { Slope angle } \\
\text { Magnitude and frequency of thermal cycles }\end{array}$ \\
& Decline in thickness & $\begin{array}{l}\text { Decrease in site slope angle } \\
\text { Decrease in rock glacier thickness } \\
\text { Decrease in temperature of the internal "core" } \\
\text { Decrease in the rate of formation of new "core" material } \\
\text { (a) decrease in the rate of debris supply } \\
\text { (b) decrease in the availability of moisture to form interstitial ice } \\
\text { Increase in horizontal velocity of the rock glacier }\end{array}$ \\
\hline
\end{tabular}


and

$$
m=\frac{\pi \rho C_{p}}{(\tau k)^{1 / 2}}
$$

where

$$
\begin{array}{ll}
x & =\text { average coefficient of linear thermal expansion } \\
\phi & =\text { angle of repose } \\
\beta & =\text { surface slope angle } \\
\delta T_{0} & =\text { maximum temperature difference during a cycle } \\
h & =\text { depth } \\
\rho & =\text { dry rock density } \\
C_{p} & =\text { specific heat of rock } \\
\tau & =\text { period of temperature cycle } \\
k & =\text { thermal conductivity of rock }
\end{array}
$$

$$
f(\phi)=\frac{(\tan \phi+1)\left(1+\sin ^{2} \phi\right)+\sqrt{ } P}{\cos ^{2} \phi}
$$

where

$$
P=(\tan \phi+1)^{2}\left[\left(1+\sin ^{2} \phi\right)^{2}-\cos ^{4} \phi\right]
$$

(Equations 1 to 4 taken from Scheidegger, 1970: 100-109.)

Assumptions inherent in this model (Scheidegger, 1970) require that (1) the layers from the surface $(h=0)$ to a depth $\left(h_{m}\right)$ at which $S_{T}$ is maximized move en masse with a displacement of $S_{T_{\max }}$ and (2) layers with $h \geq h_{m}$ act independently of surrounding layers. As a result of these assumptions, the average displacement of the ice-free layer per temperature cycle is calculated by averaging the discharge $\left(D_{1}\right)$ through the layers moving en masse $\left(h \leq h_{m}\right)$ at $S_{T_{\max }}$ with the discharge $\left(D_{2}\right)$ averaged for the layers where $h_{m} \leq h \leq h_{\max }$ with:

$$
D_{1}=S_{T \max } h_{m}
$$

Rearrangement and integration of equation 1 provides an estimate of $D_{2}$ :

$$
D_{2}=x f(\phi)\left(\frac{1}{\tan \phi-\tan \beta}\right)\left(\delta T_{0}\right) \int_{h_{\mathrm{m}}}^{h_{\max }} h e^{-m h} d h .
$$

The lower limit of this expression, found by numerical evaluation of equation 1, represents the depth at which $S_{T}$ is maximized. Displacement, however, decreases exponentially with depth. Thus, in order to obtain a meaningful average discharge $\left(D_{2}\right)$ the upper boundary $\left(h_{\max }\right)$ is set by evaluating equation 1 and selecting the depth above which $99 \%$ of the displacement occurs. Solving the integral (equation 6) yields

$$
\begin{aligned}
D_{2}= & x f(\phi)\left(\frac{1}{\tan \phi-\tan \beta}\right)\left(\delta T_{0}\right) \\
& {\left[\frac{e^{-m h}}{-m^{2}}(-m h-1)\right]_{h_{\mathrm{m}}}^{h_{\max }} . }
\end{aligned}
$$

Finally, an estimate of the annual downslope velocity of the ice-free layer $\left(V_{\text {avg }}\right)$ is obtained by

$$
V_{\text {avg }}=\left(D_{1}+D_{2}\right) / h_{\text {max }} .
$$

Values selected for constants in equations 1 to 4 (Table 5) are considered representative of the ice-free valleys. Maximum soil temperature differences and the frequency of thermal cycles measured in Wright Valley (Thompson et al., 1971; Black, 1973) are used for values of $\delta T_{o}$ and $\tau$ (Table 5). Thermodynamical constants ( $x$, $C_{p}, k$ ) derived for piles of loose granite (Scheidegger, 1970) are also used in this analysis since granite is the most frequently found lithology at rock glacier sites. Slope angles $(\beta)$, ranging from 15 to $29^{\circ}$, approximate the maximum and minimum found for rock glaciers in this study, while a range of 30 to $40^{\circ}$ (Selby, 1972) is used for an estimate of the angle of repose $(\phi)$.

The appropriateness of using the relationship developed by Scheidegger (1970) to model the activity of the upper ice-free layers is tested by comparing downslope velocities derived from equation 8 to velocities measured in this study. Minimum surface velocities ( $\leq 0.6$ to $2 \mathrm{~cm} \mathrm{yr}^{-1}$ ) measured at quadrapod stations cover the range of model velocities of 0.10 to $0.4 \mathrm{~cm} \mathrm{yr}^{-1}$ calculated from equation 8 . Scheidegger's (1970) relationships (equations 1 to 4 ) are not considered sensitive to errors in estimation of the angle of repose since velocities obtained for simulations (Table 5) with angles of repose of 30 and $40^{\circ}$ are equal. An increase in the value of $m$, comprised of thermodynamical constants (equation 2), by $20 \%$ only results in an increase in downslope velocity by $20 \%$. Finally, creep velocities of $5.4 \mathrm{~cm} \mathrm{yr}^{-1}$ were obtained by maximizing variables in equation 4 . Confidence in such high creep rates can only be established when results from quadrapod experiments on rock glaciers with surface slope angles of 30 to $35^{\circ}$ are available in the future. Scheidegger's (1970) relationships thus are considered useful for relating variations in the dry creep rate to thermal components of climatic change.

The dynamics of rock glacier "core" material are the result of deformation and hence can be related to a variety of climatic and nonclimatic causal mechanisms (Table 4). For example, a hypothetically observed decrease in horizontal velocity would result from a decline in the rock glacier site slope angle. However, the velocity of ice is also directly influenced by temperature since the strain rate produced by a given stress at a temperature of $-22^{\circ} \mathrm{C}$ is $10 \%$ of its values at $0^{\circ} \mathrm{C}$ (Paterson, 1969). Similarly, a decline in rock glacier thickness could be induced by climatically influenced decreases in the rate of debris supply or availability of moisture necessary to form interstitial ice and hence new "core" material. Alternatively, a decrease in rock-glacier thickness could also result from a nonclimatic cause such as an extension of the feature beyond its debris supply.

Fortunately, the number of causal mechanisms can be simplified at rock glacier sites in the ice-free valleys. For example, gravity induced declines in horizontal velocity 
can be eliminated as a causal mechanism at sites such as in cirques or on talus walls since the slope angle of these sites remains constant. Furthermore, the supply of debris to a rock glacier site can be assumed constant at sites near bedrock free faces. Thus, the dynamics of the "core" of rock glaciers in the ice-free valleys may be potentially related to climatic controls including temperature and the local availability of moisture necessary to form internal ice.

Rock glaciers, like true glaciers, will not respond immediately to changes in controlling parameters. Therefore, the use of rock glaciers as a proxy form of evidence in paleoclimatic studies is dependent upon the accuracy of estimating the amount of time during which the internal portion of a rock glacier adjusts to such a change. Paterson (1969) provides an estimate of the amount of time, termed the response time $(T)$, for the termini of true glaciers to adjust to a perturbation of mass balance: $T=$ $1 / 4 r$, where $r=$ longitudinal strain rate $\left(\mathrm{yr}^{-1}\right)$.

Assumptions included in this model are that (1) the velocity of the mass balance perturbation is only a function of ice thickness and glacier width and (2) the influence of changes in englacial temperature on the flow regime of the glacier can be ignored. Calculated response times are also considered to represent minima (Paterson, 1969) since diffusion of the perturbation from the head to the terminus of the glacier will serve to lengthen $T$.

A first approximation of the response time of the rock glaciers in this study is obtained by using the infinitesimal strains measured for the interstitially frozen "core" of rock glacier 01 . The resulting estimates are 740 and $250 \mathrm{yr}$, respectively. However, the yield strength of ice with a volume fraction of sand of 0.5 is reported (Hooke et al., 1972) to be twice that of clean ice at temperatures of $-7.4^{\circ} \mathrm{C}$ and stresses between 5.3 and 6.4 bar. Thus, the response time of ice-cored rock glaciers can be expected to be relatively less than that of rock glaciers with interstitially frozen debris cores. Clearly, a specific knowledge of the internal composition and flow regimes of rock glaciers is necessary to refine estimates of their response times.

In conclusion, results of this study suggest that rock glaciers are a useful tool in studies of climatic change since (1) they consist of at least two compositionally different units, the dynamics of which can be related to components of climatic change and (2) the responsiveness of these two units varies from immediate for the upper icefree layer to on the order of $10^{2}$ yr for the "core" material. Monitoring experiments on a total of eight rock glaciers are expected to yield results in 5 to $10 \mathrm{yr}$ and will serve to quantify their dynamics. These data will aid in paleoclimatic reconstructions in the ice-free valleys by (1) enabling the calculation of a range of response times for the internal portions of rock glaciers, (2) allowing the construction of paleotemperature maps for the observation period on the basis of measured changes in dry creep rates, and (3) facilitating reconstruction of localized paleomoisture trends from an understanding of the dynamics of rock glacier "cores."

\section{ACKNOWLEDGMENTS}

This research was conducted during the 1979/80 and 1980/81 austral summers under U.S. National Science Foundation grants DPP 78-21114 and DPP 79-0755. We acknowledge with great appreciation assistance in the field by R. Goldenberg, M. Bon Signor, P. Jeschke, and

TABLE 5

A numerical analysis of the dry creep rate

\begin{tabular}{|c|c|c|c|c|}
\hline Variable & Value & \multicolumn{3}{|c|}{ Source } \\
\hline$x$ & $8.3 \times 10^{-6}\left({ }^{\circ} \mathrm{C}\right)^{-1}$ & \multicolumn{3}{|c|}{ (Scheidegger, 1970: 102) } \\
\hline$\phi$ & $30-40^{\circ}$ & \multicolumn{3}{|c|}{ (Selby, 1972) } \\
\hline$\beta$ & $15-29^{\circ}$ & \multicolumn{3}{|c|}{ (This study) } \\
\hline$\delta T_{0}$ & $10-30^{\circ} \mathrm{C}$ & \multicolumn{3}{|c|}{ (Thompson et al., 1971; Black, 1973) } \\
\hline$h_{\max }$ & $20 \mathrm{~cm}$ & \multirow{2}{*}{\multicolumn{3}{|c|}{ (Rarrett and Frogoatt 1078) }} \\
\hline$\rho$ & $2.61\left(\mathrm{~g} \mathrm{~cm}^{-3}\right)$ & & & \\
\hline$C_{p}$ & $0.192 \mathrm{cal} \cdot\left({ }^{\circ} \mathrm{C} \mathrm{g}\right)^{-1}$ & \multicolumn{3}{|c|}{ (Scheidegger, 1970: 102) } \\
\hline$k$ & $3.3 \times 10^{-4} \mathrm{cal} \cdot\left(\mathrm{cm}^{\circ} \mathrm{C} \mathrm{s}\right)^{-1}$ & \multicolumn{3}{|c|}{ (Scheidegger, 1970: 102) } \\
\hline$\tau$ & $360-180{\text { cy } \mathrm{yr}^{-1}}^{-1}$ & \multicolumn{3}{|c|}{ (Thompson et al., 1971; Black, 1973) } \\
\hline \multicolumn{5}{|c|}{$\begin{array}{c}\text { Angle }(\phi) \text { of repose } \\
(\mathrm{deg})\end{array}$} \\
\hline 0.10 & 15 & 30 & 90 & 15 \\
\hline 0.10 & 15 & 40 & 90 & 15 \\
\hline 0.40 & 15 & 30 & 180 & 30 \\
\hline $0.14 * \mathrm{a}$ & 15 & 30 & 90 & 15 \\
\hline 5.4 & 29 & 30 & 180 & 30 \\
\hline
\end{tabular}

aSymbols are defined in the text (Summary and Discussion).

bValue of $m$ increase by $20 \%$ for this simulation. 
D. Yohalem; advice concerning reduction of survey data by $\mathrm{R}$. Moynihan; computer programs provided by $\mathrm{H}$. Brecher, L. Swift, and P. Davis; and drafting of figures by W. Celli. Critical reviews of the manuscript by
F. Birch, R. Moynihan, J. Reynolds, P. Carrara, S. White, and B. Allen are also gratefully acknowledged. P. Calkin first suggested the idea of monitoring these features and we are indebted to him for his foresight.

\section{REFERENCES CITED}

Akimov, A. T., 1978: Logging in shallow dry boreholes for studying geotechnical and geodynamic characteristics of frozen soils. In: USSR Contribution to the Second International Conference on Permafrost, 13-28 July 1973. Washington, D.C.: National Academy of Sciences, 452-456.

Barrett, P. J. and Froggatt, P. C., 1978: Densities, porosities and seismic velocities of some rocks from Victoria Land, Antarctica. New Zealand Journal of Geology and Geophysics, 21: $175-187$.

Barsch, D., 1977: Nature and importance of mass-wasting by rock glaciers in alpine permafrost environments. Earth Surface Processes, 2: 231-245.

, 1978: Active rock glaciers as indicators for discontinuous alpine permafrost. An example from the Swiss Alps. In: Proceedings of the Third International Conference on Permafrost, July 10-13, 1978, Edmonton, Alberta, Canada. Vol. 1. Ottawa: National Research Council of Canada, 349-352.

Barsch, D. and Hell, G., 1975: Photogrammetrische Bewegungsmessungen am Blockgletscher Murtèl I, Oberengadin, Schweizer Alpen. Zeitschrift für Gletscherkunde und Glazialgeologie, 11(2): 111-142.

Barsch, D., Fierz, H., and Haeberli, W., 1979: Shallow core drilling and borehold measurements in permafrost of an active rock glacier near the Grubengletscher, Wallis, Swiss Alps. Arctic and Alpine Research, 11: 215-228.

Bell, R. A. I., 1966: A seismic reconaissance in the McMurdo Sound region, Antarctica. Journal of Glaciology, 6(44): 209-221.

Black, R. F., 1973: Cryomorphic processes and micro-relief features, Victoria Land, Antarctica. In Fahey, B. D. and Thompson, R. D. (eds.), Research in Polar and Alpine Geomorphology: Third Guelph Symposium on Geomorphology, University of Guelph, 1973. Norwich, England: GeoAbstracts, 11-24.

Bogolyubov, A. N., 1978: Investigation of dependence of specific resistance of unconsolidated frozen deposits in original bedding on cryogenous textures and temperature. In: USSR Contribution to the Second International Conference on Permafrost, 13-28 July 1973. Washington, D.C.: National Academy of Sciences, 482-485.

Bouchard, H. and Moffitt, R. H., 1965: Surveying, 5th edition. Scranton, Penn.: International Textbook Co. 754 pp.

Bull, C., 1966: Climatological observations in ice-free areas of southern Victoria Land, Antarctica. In Rubin, M. J. (ed.), Studies in Antarctic Meteorology. Antarctic Research Series 9. Washington, D.C.: American Geophysical Union, 177-194.

Calkin, P. E., 1964: Geomorphology and glacial geology of the Victoria Valley system, southern Victoria Land, Antarctica. The Ohio State University, Institute of Polar Studies Report, 10. $66 \mathrm{pp}$.

, 1971: Glacial geology of the Victoria Valley system, southern Victoria Land, Antarctica. In Crary, A. P. (ed.), Antarctic Snow and Ice II. Antarctic Research Series 16. Washington, D.C.: American Geophysical Union, 363-412. Colacino, M. and Stocchino, C., 1978: The microclimate of an
Antarctic Dry Valley (Taylor Valley, Victoria Land). Polar Geography, 2(3): 137-153.

Corte, A. E., 1976: Rock glaciers. Biuletyn Peryglacjalny, 26: 175-197.

Davis, P. A., 1979: Development and application of resistivity sounding inversion for several field arrays. M.S. thesis, University of Minnesota. $153 \mathrm{pp}$.

Dawson, A. G., 1977: A fossil lobate rock glacier in Jura. Scottish Journal of Geology, 13(1): 37-42.

Dobrin, M., 1976: Introduction to Geophysical Prospecting. 3rd edition. New York: McGraw-Hill. 630 pp.

Dzhurik, V. and Leshchivo, F. N., 1978: Experimental investigations of seismic properties of frozen soils. In: USSR Contribution to the Second International Conference on Permafrost, 13-28 July 1973. Washington, D.C.: National Academy of Sciences, 485-491.

Ellis, J. M. and Calkin, P. E., 1979: Nature and distribution of glaciers, Neoglacial moraines, and rock glaciers, eastcentral Brooks Range, Alaska. Arctic and Alpine Research, 11: 403-420.

Fisch, W., Sen., Fisch, W., Jr., and Haeberli, W., 1977: Electrical D.C. resistivity soundings with long profiles on rock glaciers and moraines in the Alps of Switzerland. Zeitschrift für Gletscherkunde und Glaziolgelogie, 13(1-2): 239-260.

Haeberli, W., King, L., and Flotron, A., 1979: Surface movement and lichen-cover studies at the active rock glacier near Grubengletscher, Wallis, Swiss Alps. Arctic and Alpine Research, 11: 421-441.

Harris, S. A., 1981: Distribution of active glaciers and rock glaciers compared to the distribution of permafrost landforms, based on freezing and thawing indices. Canadian Journal of Earth Sciences, 18: 376-381.

Hassinger, J. M., 1981: Characteristics, dynamics, and paleoclimatic significance of rock glaciers in southern Victoria Land, Antarctica. M.S. thesis, University of New Hampshire. $134 \mathrm{pp}$.

Hochstein, M. J., 1967: Electrical resistivity measurements on ice sheets. Journal of Glaciology, 6(47): 623-633.

Hooke, R. LeB., Dahlin, B. B., and Kauper, M. T., 1972: Creep of ice containing dispersed fine sand. Journal of Glaciology, 11(63): $327-336$.

Hunter, J. A. M., 1973: The application of shallow seismic methods to mapping of frozen surficial materials. In: North American Contribution to the Second International Permafrost Conference, 13-28 July 1973. Washington, D.C.: National Academy of Sciences, 527-535.

Jaeger, J. C., 1956: Elasticity, Fracture, and Flow with Engineering and Geological Applications. London: Methuen. $267 \mathrm{pp}$.

Johnson, J. P., 1973: Some problems in the study of rock glaciers. In Fahey, B. D. and Thompson, R. D. (eds.), Research in Polar and Alpine Geomorphology: Proceedings 3rd Guelph Symposium on Geomorphology, University of Guelph, 1973. Norwich, England: GeoAbstracts, 84-94.

Larin, S. M., Marov, G. P., Kholmyanskiy, M., and Neizvestnov, Ya. V., 1978: Certain types of geoelectric sections of the 
negative temperature belt in the arctic and subarctic in connection with exploration for subpermafrost water. In: USSR Contribution to the Second International Conference on Permafrost, 13-28 July 1973. Washington, D.C.: National Academy of Sciences, 428-430.

Lillesand, T. M. and Keifer, R. W., 1979: Remote Sensing and Image Interpretation. New York: Wiley. $610 \mathrm{pp}$.

Luckman, B. H. and Crockett, K. J., 1978: Distribution and characteristics of rock glaciers in the southern part of Jasper National Park, Alberta. Canadian Journal of Earth Sciences, 15: $540-550$.

Mayewski, P. A. and Hassinger, J. M., 1980: Characteristics and significance of rock glaciers in southern Victoria Land, Antarctica. Antarctic Journal of the United States, 15(5): 68-69.

McGinnis, L. D. and Jensen, T. E., 1971: Permafrost-hydrologic regimen in two ice-free valleys, Antarctica, from electrical depth sounding. Quaternary Research, 1: 389-409.

McGinnis, L. D., Nakao, K., and Clark, C. C., 1973: Geophysical identification of frozen and unfrozen ground, Antarctica. In: North American Contribution to the Second International Permafrost Conference, 13-28 July 1973. Washington, D.C.: National Academy of Sciences, 136-146.

McKelvey, B. C. and Webb, P. N., 1962: Geological investigations in south Victoria Land, Antarctica: geology of Wright Valley. New Zealand Journal of Geology and Geophysics, 5: 143-162.

McSaveney, M. J., 1973: Relative yearly totals of solar radiation incident on various slopes for latitude $77^{\circ} 30^{\prime} S$. Antarctic Journal of the United States, 8(6): 347-348.

Meyer, A. U. and Röthlisberger, H., 1962: Electrical DC resistivity measurements on glacier ice near Thule, Greenland. U.S. Army CRREL Technical Report 87. 34 pp.

$\rightarrow$ Morris, S., 1981: Topoclimatic factors and the development of rock glacier facies, Sangre de Cristo Mountains, southern Colorado. Arctic and Alpine Research, 13: 329-338.

Mudrey, M. G., Torii, T., and Harris, H., 1975: Geology of DVDP 13-Don Juan Pond, Wright Valley, Antarctica. Dry Valley Drilling Project (DVDP) Bulletin, 5: 78-93.

Ommanney, C. S. L., 1976: Canadian rock glacier studies: paper presented at Canadian Association of Geographers annual meeting, Laval University, Quebec City. 27 pp.

Orellana, E. and Mooney, H., 1966: Master curves and tables for vertical electrical sounding over layered structures. Interciencia Costanlla de los Angles [Madrid], 15. $160 \mathrm{pp.}$

Osborn, G. D., 1975: Advancing glaciers in the Lake Louise area, Banff National Park, Alberta. Canadian Journal of Earth Sciences, 12: 1060-1062.

Østrem, G., 1964: Ice-cored moraines in Scandinavia. Geografiska Annaler, 46: 282-337.

Outcalt, S. I. and Benedict, J. B., 1965: Photo interpretation of two types of rock glaciers in the Colorado Front Range, U.S.A. Journal of Glaciology, 5(42): 849-856.

Paterson, W. S. B., 1969: Physics of Glaciers. Oxford: Pergamon Press. 250 pp.

Potter, N., Jr., 1972: Ice-cored rock glacier, Galena Creek, Northern Absaroka Mtns., Wyoming. Geological Society of America Bulletin, 83: 3025-3058.

Reynolds, J. M. and Paren, J. G., 1980: Recrystallization and electrical behaviour of glacier ice. Nature, 283(5742): 63-64.
Röthlisberger, H., 1967: Electrical resistivity measurements and soundings on glaciers. Journal of Glaciology, 6(47): 599-606. , 1972: Seismic exploration in cold regions. U.S. Army CRREL Monograph, II-A 2a. 129 pp.

Röthlisberger, H. and Vögtli, K., 1967: Recent D-C resistivity soundings on Swiss glaciers. Journal of Glaciology, 6(47): 607-621.

Scheidegger, A., 1970: Theoretical Geomorphology. Englewood Cliffs, N.J.: Prentice-Hall. 333 pp.

Selby, M., 1972: Antarctic tors. Zeitschrift für Geomorphologie, Suppl., 13: 73-86.

Shaw, J. and Healy, T. R., 1977: Rectilinear slope formation in Antarctica. Annals of the Association of American Geographers, 67: 46-54.

Swift, L. W., Jr., 1976: Algorithm for solar radiation on mountain slopes. Water Resources Research, 12: 108-112.

Telford, W. M., Geldart, L. P., Sheriff, R. E., and Keys, D. A., 1976: Applied Geophysics. London: Cambridge University Press. 843 pp.

Thiokol, 1964: Geochrone Handbook. Brison, Penn.: Thiokol Chemical Corporation of America.

Thompson, D. C., Craig, R. M. F., and Bromley, A. M., 1971: Climate and surface heat balance in an Antarctic Dry Valley. New Zealand Journal of Science, 14: 245-251.

Twomey, A. A., 1968: Seismic refraction studies in surficial materials of Victoria Land, Antarctica. M.S. thesis, University of Wisconsin. $85 \mathrm{pp}$.

Vick, S., 1981: Morphology and the role of landsliding of some rock glaciers in the Mosquito Range, Colorado. Geological Society of America Bulletin, 92: 75-84.

Vögtli, K. J., 1967: D.C. resistivity soundings on Devon Island, NWT, Canada. Journal of Glaciology, 6(47): 634-642.

Voronkov, O. K. and Mikhaylovskiy, G. V., 1978: Study of underground ice by the method of seismic exploration. In: USSR Contribution to the Second International Conference on Permafrost, 13-28 July 1973. Washington, D.C.: National Academy of Sciences, 491-494.

Wahrhaftig, C. and Cox, A., 1959: Rock glaciers in the Alaska Range. Geological Society of America Bulletin, 70: 383-430.

Washburn, A. L., 1980: Geocryology: A Survey of Periglacial Processes and Environments. New York: Wiley. 406 pp.

White, S. E., 1971: Rock glacier studies in the Colorado Front Range, 1961-1968. Arctic and Alpine Research, 3: 43-64.

- 1976: Rock glaciers and block fields: review and new data. Quaternary Research, 6: 77-97.

$\longrightarrow$, 1981: Alpine mass movement forms (noncatastrophic): classification, description, and significance. Arctic and Alpine Research, 13: 127-137.

Wilson, A. T., 1979: Geochemical problems of the Antarctic dry areas. Nature, 280(5719): 205-208.

Zykov, Yu. D. and Baulin, Yu. I., 1978: Potentialities of seismicacoustic techniques in engineering-geologic investigations for construction of permafrost. In: USSR Contribution to the Second International Conference on Permafrost, 13-28 July 1973. Washington, D.C.: National Academy of Sciences, 495-497. 